DIVISION OF THE HUMANITIES AND SOCIAL SCIENCES

CALIFORNIA INSTITUTE OF TECHNOLOGY

PASADENA, CALIFORNIA 91125

TO ELECT OR TO APPOINT? BIAS, INFORMATION, AND RESPONSIVENESS OF BUREAUCRATS AND POLITICIANS.

Matias laryczower, Garrett Lewis and Matthew Shum

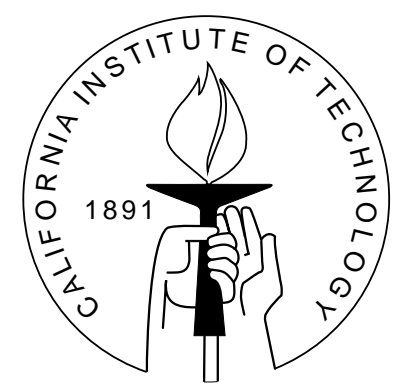

SOCIAL SCIENCE WORKING PAPER 1323

May 2010 


\title{
To Elect or to Appoint? Bias, Information, and Responsiveness of Bureaucrats and Politicians.
}

\author{
Matias Iaryczower, Garrett Lewis and Matthew Shum
}

\begin{abstract}
In this paper, we address empirically the trade-offs involved in choosing between bureaucrats and politicians. In order to do this, we need to map institutions of selection and retention of public officials to the type of public officials they induce. We do this by specifying a collective decision-making model, and exploiting its equilibrium information to obtain estimates of the unobservable types. We focus on criminal decisions across US states' Supreme Courts. We find that justices that are shielded from voters' influence ("bureaucrats") on average (i) have better information, (ii) are more likely to change their preconceived opinions about a case, and (iii) are more effective (make less mistakes) than their elected counterparts ("politicians"). We evaluate how performance would change if the courts replaced majority rule with unanimity rule.
\end{abstract}

JEL classification numbers: D72, D78, C13

Key words: bureaucrats, elected officials, strategic voting, common values, structural estimation, mixture model 


\title{
To Elect or to Appoint? Bias, Information, and Responsiveness of Bureaucrats and Politicians.*
}

\author{
Matias Iaryczower, Garrett Lewis and Matthew Shum ${ }^{\dagger}$
}

\section{Introduction}

The basic principle of representative democracy dictates that all legislative and top executive positions in public office are to be occupied by elected representatives (politicians). But besides this broad guiding principle, the idea of representation in the operation of government is much more muddled. In all modern democracies, a number of public positions of great influence are held by non-elected officials (bureaucrats). Examples for the US include the Supreme Court, the Federal Reserve Board, and federal agencies.

The different methods of selection and retention of public officials induce differences in the performance of government. Working well, elections may induce public officials to act in the public interest, even when their preferences are not aligned with those of the public. This is the disciplining role of elections emphasized by Barro (1973) and Ferejohn (1986). Working badly, elections can also induce an official who has more information than the public to pander to the public, choosing not the appropriate action, but instead the most popular action (Maskin and Tirole (2004), Canes-Wrone and Shotts (2007)). Elections can also induce officials to divert resources away from developing expertise (Alesina and Tabellini (2007)).

Given these various competing effects, it is ultimately an empirical question how politicians and bureaucrats differ in type and performance. First, there are selection effects: do voters select different types of public officials - more or less biased, better or worst at gathering and processing information -than government officials? Second, there are incentive effects: do reelection induce public officials to improve their proficiency to deal with the flow of information of each decision? Do they induce them to be more responsive to the public? Third, differences in type affect performance: are bureaucrats more effective than politicians?

*We thank Yosh Halberstam, Jean-Laurent Rosenthal, Matt Spitzer, and participants in seminars at NYU, Northwestern-Kellogg, and UC Davis for useful comments to a previous version of this paper.

$\dagger$ Division of Humanities and Social Sciences, California Institute of Technology, Pasadena, California 91125, USA, emails: miaryc@hss.caltech.edu, gdl@caltech.edu, and mshum@caltech.edu. 
In this paper, we tackle these questions. We build on the foundations laid by a large literature, which provides overwhelming evidence that bureaucrats and politicians produce different public policy outcomes. Here we extend this research line to the next step. Our starting premise is that in order to understand the trade-offs inherent in choosing between bureaucrats and politicians, we need to map institutions to the type of public officials they induce. The difficulty, of course, is that this type is unobservable. The contribution of this paper is to bridge this gap. We do this by specifying a decision-making model, and using equilibrium information to recover the unobservable types. The main idea is to exploit the information contained in the joint observation of the individual decisions of members of committees that deal with issues involving both ideological considerations and common values. The underlying common value induces correlation in votes in equilibrium, which allows us to disentangle bias and quality of information.

We focus here on criminal decisions in US states' Supreme Courts. The application suits the approach perfectly for two reasons. First, selection and retention methods vary across states: while in some states supreme court justices are elected, in others they are appointed by elected officials. Moreover, non-elected justices are appointed for life in some states, but must face a political reappointment or an up-or-down retention election by voters in other states. Second, as other high courts, state supreme courts are committees making decisions on issues in which there is an underlying common value component; a correct decision under the law. ${ }^{1}$ This is particularly transparent in criminal cases, in which the relevant uncertainty falls more heavily on the specifics of the case than on the interpretation of the law in a given situation.

Incorporating elements of common values does not mean ruling out disagreement. The decision of the court will typically balance the members' goal of reaching a correct decision, with conflict among them in terms of what is the correct decision in each case. This conflict arises naturally in the relatively complex cases considered by the high courts because of differences in the information processed by each justice, because of differences in their ability to produce and evaluate case-specific information, and because of idiosyncratic biases in how justices approach different cases. ${ }^{2}$

In the model, we assume that the goal of any justice $i$ in any given case $t$ is to rule according to $i$ 's own best understanding of how the law applies to the particulars of the case. Specifically, we assume that in each case $t$, a justice's understanding of the particulars of the case is summarized by a private signal, with precision $\theta_{i t}$. The

\footnotetext{
${ }^{1}$ Decision-making in the court is different than in a legislature. Judging entails understanding the body of the law and the details of the case under consideration in order to interpret the meaning of the law as it applies to the case. As Supreme Court Justice Ruth Ginsburg put it, "[E]ach case is based on particular facts and its decision should turn on those facts and the governing law, stated and explained in light of the particular arguments the parties or their representatives choose to present." (From the statement submitted to the Senate Committee on the Judiciary by Justice Ruth Ginsburg.) This is also emphasized by Cameron and Kornhauser (2008), among others.

${ }^{2}$ Justices' biases can, but do not necessarily reflect ideological considerations. These preconceptions about how the law maps to the particulars of each case can also reflect ingrained theoretical arguments about the law, personal experiences, and other determinants for a non-neutral approach to this case.
} 
imprecision of the signal leaves room for interpretation, which in turn allows ideological biases to come into play. This bias boils down to a threshold $\pi_{i t}$ such that the justice prefers to rule for the Plaintiff in case $t$ if and only if the probability that the law favors the Plaintiff is at least $\pi_{i t}$. Information precision and bias then interact to produce outcomes. Higher precision means that it is typically more clear for the justice whether the ruling should favor the Plaintiff or the Defendant according to the body of law. A larger bias means that despite her case information, a justice persists in going with her preconception of how to rule in a case like this. In the extreme, with $\pi_{i t} \approx 0$ (or $\pi_{i t} \approx 1$ ), justice $i$ will vote almost completely in line with her ideology. On the other hand, when $\pi_{i t}=1 / 2$ for all $i$, justices are ideologically unbiased, and vote solely based on their information.

In the estimation, we recover the values of $\left(\theta_{i t}, \pi_{i t}\right) \mid X_{t}$ for each justice $i$ conditioning on observable characteristics of the cases and the justices, including experience variables (prior judicial and political experience, experience in the state supreme court), context variables (measures of the political preferences of voters and politicians at the time of appointment and at the time of decision), and institutional variables (whether the justice was elected, appointed for an original term subject to a political reappointment or a retention election, or appointed for life). We do this for two variants of the model: the expressive voting model (where justices care about getting their decision right), and the strategic voting model (Austen-Smith and Banks (1996), Feddersen and Pesendorfer (1997, 1998)), where justices are concerned about getting the court's decision right, and therefore "learn" from their peers in equilibrium. ${ }^{3}$ We also estimate justices' common prior belief $\rho$ that the law favors the Plaintiff given case characteristics $X$. This also captures inherent differences across states in the types of cases heard by the state supreme courts.

The main results clarify the trade-offs inherent in choosing between bureaucrats and politicians. First, justices that are shielded from voters' evaluations ("bureaucrats") on average have higher quality of information than justices that face either reelection or retention elections ("politicians"). In fact, the quality of information of justices that are shielded from voters' influence is on average $25 \%$ larger than that of justices facing retention elections, and $30 \%$ larger than that of justices that are elected. Institutions of selection and retention of justices also affect justices' bias (justices that are not shielded from voters are more moderate on average), but this effect is more modest in magnitude.

These two components of justices' type - quality and bias - affect how the justices' information is reflected in their voting behavior. We find that justices who are shielded from voters not only have better information, but are also more likely than elected justices to change their preconceived opinions about a case. We quantify the flexibility of a judge to incorporate case-specific information with the FLEX measure introduced in Iaryczower and Shum (2009). This is the probability that a judge votes differently than what she would have voted for in the absence of case-specific information. We show that the

\footnotetext{
${ }^{3}$ In the law and economics literature, this distinction is referred to as whether judges are consequentialist or non-consequentialist (see Cameron and Kornhauser (2008)).
} 
average FLEX score for elected justices (36\%) is lower than that of justices appointed for life $(41 \%)$.

Our estimation and modeling approach also allows us to assess directly the effect of institutions on the performance of the court, as measured by the probability that the court reaches an incorrect decision. While these error rates are small overall, we find that justices appointed for life and appointed justices with a political reappointment on average have a lower probability of reaching an incorrect decision $(0.1 \%)$ than both justices that face retention elections $(0.4 \%)$, and justices that are elected $(0.9 \%)$.

While state supreme courts typically have a relatively low total error rate, the pattern of mistakes is highly asymmetric. At both the individual level and at the court level, on average justices make comparatively large mistakes in favor of the Plaintiff. ${ }^{4}$ This begs the question as to how the effectiveness of the courts would change if simple majority rule (the voting rule currently in use) were replaced by a decision-making rule that tilts the balance in favor of the Defendant. In particular, we consider a change to a unanimity rule in which ruling against the Defendant requires the consent of all justices.

In both the strategic and the expressive voting model, introducing the change to unanimity rule would have major consequences for public outcomes and the effectiveness of the courts. In the expressive voting model, where justices care about their vote only, replacing majority rule by unanimity rule does achieve the purpose of reducing the probability of an incorrect court decision in favor of the Plaintiff, but only by dramatically increasing the probability of an incorrect court decision in favor of the Defendant (reaching $33 \%$ for elected justices and 35\% for non-elected justices facing retention elections). The strategic voting model predicts large changes in the opposite direction. As a result of the move to unanimity, strategic justices who care about the decision of the court would modify their strategy in equilibrium, becoming harsher against the Defendant. As a result, the move to unanimity would significantly increase the probability of a mistaken decision against the Defendant (reaching $21 \%$ for elected justices).

The rest of the paper is organized as follows. Section 2 contains a literature review. Section 3 introduces the theoretical model of collective decision-making in the court and characterizes equilibrium outcomes. Section 4 describes the estimation procedure. Section 5 presents the main results. Section 6 concludes.

\section{Related Literature}

The theoretical literature on bureaucrats and politicians builds on the seminal contributions of Barro (1973) and Ferejohn (1986), which provide the foundations of the theory of elections as disciplining device. Barro (1973) introduces the main idea that voters can

\footnotetext{
${ }^{4}$ To compare this with the ex ante probability of an incorrect decision, the probability of a mistake favoring the Plaintiff when the Defendant should win is $0.3 \%$ for justices that are isolated from voters, $1.1 \%$ for justices facing retention elections and $2.6 \%$ for justices facing competitive reelections.
} 
limit (but not eliminate) rent extraction by elected politicians by making their reelection conditional on observed behavior. The optimal rule limits rents as much as possible, while still making it attractive for the politician to want to get reelected. Ferejohn (1986) formalizes a similar idea within a moral-hazard framework (voters' payoffs depend on the - unobservable, costly - effort exerted by the politician), and derives the optimal retrospective voting rule. Banks and Sundaram (1998) study the optimal retention rule for voters in a model that incorporates both moral hazard and adverse selection. CanesWrone, Herron, and Shotts (2001) consider a model in which elected officials have the same preferences as the electorate, and the incumbent attempts to signal talent (e.g., more precise information). They conclude that elected officials will pander (choose the popular, ex ante preferred action) only under some limited conditions. Canes-Wrone and Shotts (2007), however, show that elected officials will be more inclined to pander when there is uncertainty regarding their congruence with the electorate.

Maskin and Tirole (2004) and Alesina and Tabellini (2007, 2008) explicitly compare bureaucrats and politicians. Maskin and Tirole (2004) introduce a lack of congruence between voters and public officials. It is assumed that the official values office per se, and also has a legacy motivation. When the office-holding motive is strong, politicians want to pander, but when the office motivation is weak, they are guided by the legacy motivation. Maskin and Tirole (2004) conclude that non-elected officials (bureaucrats, or "judges") are preferred when the public is poorly informed about what the optimal action is, and when feedback about the quality of the decision is limited. Alesina and Tabellini (2007) models career concerns of bureaucrats (appointed officials) and politicians (elected representatives). Politicians want to win elections to retain their seats, and thus have to be perceived as having a higher ability than the replacement candidate from the pool. Bureaucrats are motivated by career concerns: they want to increase their perceived ability, to improve as much as possible their external professional prospects. As in Ferejohn (1986), or Banks and Sundaram (1998), effort is unobservable, and interacts with ability (additively) to produce outcomes. Alesina and Tabellini (2007) conclude that bureaucrats are preferred in technical tasks for which ability is more important than effort, or when there is large uncertainty about whether the policymaker has the required abilities to fulfill her task.

A key common element in these theoretical approaches is that the type of government official is unknown. The key factor driving the results is the amount of information that is revealed in different institutional settings about unobservable characteristics of public officials (their preferences, their competence, or the readiness to exert effort). To the best of our knowledge, this key feature has not been incorporated into applied research on the topic. There is, however, a wealth of empirical research motivated by the same underlying questions that inspired the theoretical literature.

First, a number of papers show that elected and appointed government officials do in fact behave differently. This, in particular, is the case of elected and appointed regulators (see Besley and Case (2003) for a survey) and elected and appointed judges in 
the US states. ${ }^{5}$ Hanssen (2000) shows that states with elected judges have significantly smaller bureaucracies. He interprets this as evidence that elected judges are more independent. Hanssen (2004) shows that institutions that diminish the ability of politicians to determine whether a judge remains in office are associated with closer competition between political parties, and with larger differences in party platforms, while the least independence-enhancing institutions are associated with a stronger single party control. Besley and Payne (2005) show that states that appoint their judges have lower levels of discrimination charges compared to those that use some form of election. Gordon and Huber (2007) analyze the sentencing behavior of district court judges that are elected and appointed (facing a subsequent retention election) in the state of Kansas. They show that close to the elections, elected judges are harsher in sentencing relative to appointed judges. ${ }^{6}$

Choi, Gulati, and Posner (forthcoming) also focus on state Supreme Court judges, and shares our emphasis on measuring the effects of the judicial selection process on non-ideological characteristics of the judges. Their methodology is quite different, as they focus on opinions instead of voting, and directly find observable proxies of judges' qualities, including the number of opinions written, and the number of times a judge's opinions were cited by other courts at the same level of the judicial hierarchy. In contrast, we focus on the individual votes to decide the position of the court, and consider a structural equilibrium model of voting which allows us to "back out" estimates of judges' bias and quality of information as a function of the judicial selection mechanism. ${ }^{7}$ Also taking a more structural approach is Lim (2008), who estimates a structural model that fully incorporates career concerns into judges' behavior, using sentencing data from Kansas. ${ }^{8}$ With this she shows that the sentencing behavior of elected judges is in fact an important determinant of their reelection. ${ }^{9}$ She also shows that while the sentencing behavior of appointed judges does not vary much with the political orientation of the district, elected justices tend to be more lenient in liberal leaning districts.

Lim's model is a purely ideological model, which precludes the possibility of common values and dispersed information which seem central to the nature of decision-making in the court. This is a common feature of the empirical literature on voting in committees thus far, as the theory of voting with common value elements and dispersed information was developed fairly recently, following the seminal contributions of Austen-Smith and

\footnotetext{
${ }^{5}$ Relatedly, Besley and Reynal-Querol (2010) study whether democracies select higher-quality (more educated) leaders relative to autocracies, using a unique cross-country data spanning the last two centuries.

${ }^{6}$ More broadly, there is overwhelming evidence showing that judges are sensitive to the political environment. See Brace and Hall (1990, 1993, 1997) for US states, Gely and Spiller (1990); Spiller and Gely (1992) for the US Supreme Court, Helmke (2002) and Iaryczower, Spiller, and Tommasi (2002, 2006) for the Supreme Court in Argentina, along many others.

${ }^{7}$ Choi, Gulati, and Posner (forthcoming) conclude that appointed judges write higher quality opinions than elected judges do, but elected judges write more opinions.

${ }^{8}$ See Diermeier, Keane, and Merlo (2005) for a similar approach in Congress.

${ }^{9}$ Note that this is a surprising finding, given that according to the previous literature, voters are very uninformed about judges' decisions in the vast majority of cases (see Gordon and Huber (2007) and references within, and Bonneau and Hall (2006) and references within).
} 
Banks (1996), and Feddersen and Pesendorfer (1997, 1998). ${ }^{10}$ In this paper we follow the approach that we introduced in Iaryczower and Shum (2009) to deal with ideology and common values in the context of equilibrium behavior (for a connected approach, see Iaryczower, Katz, and Saiegh (2009)). ${ }^{11}$ Our model of collective decision-making is close to that of Duggan and Martinelli (2001), although here players' preferences are public information.

An interesting issue in connection to strategic voting in this setting is the possible impact of pre-vote deliberation on outcomes. The main question is whether strategic agents will use pre-vote deliberation to communicate information to their peers, or whether they will use these arguments to try to influence their opinion, possibly not revealing some information that can be harmful to their case, or exaggerating evidence one way or the other. While the incentive to do so is small when interests are well aligned (Coughlan (2000)), this is not the case when there is (interim) disagreement, as in the setting consider here. This makes truthful revelation of information more difficult, as is illustrated in the analysis of Austen-Smith and Feddersen (2005, 2006) (see also Li, Rosen, and Suen (2001) and Doraszelski, Gerardi, and Squintani (2003)). ${ }^{12}$ Visser and Swank (2007) consider pre-vote deliberation when committee members want to signal their ability to a principal. Reputation concerns here induce committee members to misrepresent their information in deliberations but, in spite of this, they always vote unanimously. This is because in this setting, disagreement signals lack of competence.Visser and Swank's basic logic - that information is reflected in the variation of the justices' votes - also underlies the identification of the key model parameters from the observed vote data (see Section 4). However, in our setting votes provide information about not only justices' ability (quality of information), but also their bias.

\section{A Model of Decision-Making in the Court}

In this section, we describe the model of collective decision-making in the courts. In doing so, we take the parameters of the problem as given, and their dependence on publicly

\footnotetext{
${ }^{10}$ For structural estimation of ideological models of voting in committees (that do not directly incorporate career concerns) see Poole and Rosenthal (1985, 1991), Heckman and Snyder (1997), Londregan (1999), Clinton, Jackman, and Rivers (2004) - for the US Congress- and Martin and Quinn (2002, 2007) - for the US Supreme Court. Degan and Merlo (2008) and de Paula and Merlo (2009) consider the nonparametric identification and estimation of the ideological voting model. Coate and Conlin (2004), Coate, Conlin, and Moro (2008), and Kawai and Watanabe (2009) also perform structural estimation of strategic voting (ie. "pivotal voting") models with ideological voters.

${ }^{11}$ With common values and dispersed information, strategic considerations - which are absent in the sincere voting spatial model - come into play. Our methodology deals with these strategic considerations. Londregan (1999), Clinton and Meirowitz (2003) and Clinton and Meirowitz (2004), who analyze the spatial voting model without assuming sincere voting, paying attention to agendas and sequence.

${ }^{12}$ If agents send not only relevant information, but also other (random) messages, which the group uses to define correlated voting strategies, more can be done. Gerardi and Yariv (2007) show that every outcome that can be implemented with a non-unanimous voting rule $r$ can also be implemented (as a sequential equilibrium of a cheap talk extension of the voting game) with a non-unanimous rule $r^{\prime}$. This obviously enlarges the set of possible equilibrium outcomes for each given voting rule.
} 
observable characteristics of the choice situation as understood. We make this relation explicit in Section 4.

The court is composed of $n$ justices, $i=1, \ldots, n$, who consider $T$ independent cases, $t=1, \ldots, T$. In each case $t$, justice $i$ can rule in favor or against the Defendant. We denote this ruling by $v_{i}^{t} \in\{0,1\}$, with $v_{i}^{t}=0$ indicating a ruling in favor of the Defendant and $v_{i}^{t}=1$ a ruling in favor of the Plaintiff. The court aggregates the decisions of the individual justices by simple majority rule; i.e. rules in favor of the Plaintiff $\left(v_{t}=p\right)$ if $\sum_{i} v_{i}^{t} \geq R_{s} \equiv \frac{n+1}{2}$ and in favor of the Defendant $\left(v_{t}=d\right)$ otherwise.

We consider two related models of individual behavior. In the expressive voting model, we assume that in deciding their vote, justices care only about their individual vote. In the strategic or outcome-oriented voting model, we assume instead that justices care about the ruling of the court. We assume that the goal of any justice $i$ in any given case $t$ is that she (in the expressive voting model) or the court (in the strategic voting model) rules according to $i$ 's own best understanding of how the law applies to the particulars of the case.

Specifically, before ruling in each case $t$, each justice $i$ observes a private signal $s_{i t}=$ $\omega_{t}+\sigma_{i t} \varepsilon_{i t}$, where $\varepsilon_{i t} \sim \mathcal{N}(0,1)$. Here $\omega_{t} \in\{0,1\}$ in an unobservable variable - for both the econometrician and the justices - indicating whether the meaning of the law favors the Plaintiff $\left(\omega_{t}=1\right)$ or the Defendant $\left(\omega_{t}=0\right)$, and $\theta_{i t}=1 / \sigma_{i t}$ is a scale parameter that parametrizes the informativeness of $i$ 's signals. ${ }^{13}$ This parameterization of the information structure satisfies the Monotone Likelihood Ratio Property (MLRP), which is important in what follows.

Justices care about this information because their payoffs are state dependent. In particular, we assume that given $\pi_{i t} \in(0,1)$, justice $i$ has a payoff of $-\pi_{i t}$ when the law favors the Defendant but she/the court rules in favor of the Plaintiff $\left(v_{t}=1\right.$ when $\left.\omega_{t}=0\right)$ and of $-\left(1-\pi_{i t}\right)$ when the law favors the Plaintiff but instead she/the court rules in favor of the Defendant $\left(v_{t}=0\right.$ when $\left.\omega_{t}=1\right) .{ }^{14}$ The payoffs of $v_{t}=\omega_{t}=0$ and $v_{t}=\omega_{t}=1$ are normalized to zero. Thus given information $E$, Justice $i$ votes to rule against the Defendant in $t$ if and only if $\operatorname{Pr}^{i}\left(\omega_{t}=1 \mid E\right) \geq \pi_{i t}$. Equivalently, justice $i$ votes to rule against the Defendant in case $t$ given $E$ if and only if the likelihood ratio $\operatorname{Pr}^{i}\left(E \mid \omega_{t}=1\right) / \operatorname{Pr}^{i}\left(E \mid \omega_{t}=0\right)$ is larger than $\frac{\pi_{i t}}{1-\pi_{i t}} \frac{1-\rho_{t}}{\rho_{t}}$, where $\rho_{t} \equiv \operatorname{Pr}\left(\omega_{t}=1\right)$ denotes justices' common prior probability of the unobserved state $\omega_{t}$. Note that since $\omega_{t}$ is assumed to be unobservable, there is always information that would make any two justices disagree about a case. Moreover, if sufficiently biased, two justices can disagree almost always. In particular, with $\pi_{i t} \approx 0$ (or $\pi_{i t} \approx 1$ ), justice $i$ is almost always

\footnotetext{
${ }^{13}$ We write $\theta_{i t}$ and not simply $\theta_{i}$, invariant in $t$, because in the estimation we will allow the precision of information to depend on characteristics of the case. With identical observable characteristics across cases we would have $\theta_{i t}=\theta_{i}$ for all $t$. The same remark applies to the bias $\pi_{i t}$ below.

${ }^{14}$ Thus, $\pi_{i} \neq 1 / 2$ reflects a bias towards the Plaintiff or the Defendant. These preconceptions about how the law maps to the particulars of each case can reflect a variety of factors inducing a non-neutral approach to this case, such as ingrained theoretical arguments about the law, personal experiences, or ideological considerations.
} 
ideological. On the other hand, when $\pi_{i t}=1 / 2$ for all $i$, the setting boils down to an unbiased, pure common values model. ${ }^{15}$

The two alternative models of behavior differ in how much information each justice has in equilibrium. In the expressive voting model, justices care about their own ruling, and therefore vote based on their own information $s_{i t}$, i.e., rule against the Defendant whenever $\operatorname{Pr}^{i}\left(\omega_{t}=P \mid s_{i t}\right) \geq \pi_{i t}$. Then $E$ consists only of $s_{i t}$, and $i$ votes to rule against the Defendant if

$$
\frac{\operatorname{Pr}\left(s_{i t} \mid \omega_{t}=1\right)}{\operatorname{Pr}\left(s_{i t} \mid \omega_{t}=0\right)}=\frac{\phi\left(\theta_{i t}\left[s_{i t}-1\right]\right)}{\phi\left(\theta_{i t} s_{i t}\right)} \geq \frac{\pi_{i t}}{1-\pi_{i t}} \frac{1-\rho_{t}}{\rho_{t}}
$$

Let $s_{i t}^{\text {exp }}$ denote the value of $s_{i t}$ that solves (1) with equality. By the MLRP the ratio $L(s) \equiv \operatorname{Pr}\left(s \mid \omega_{t}=1\right) / \operatorname{Pr}\left(s \mid \omega_{t}=0\right)$ is increasing in $s$, so that $i$ rules against the Defendant whenever $s_{i t} \geq s_{i t}^{e x p}$, and in favor of the Defendant otherwise. These cutoff points $s_{i t}^{\text {exp }}$ for $i=1, \ldots, n$ completely characterize behavior in the expressive voting case. Therefore we can write the likelihood of the justices' votes in case $t$ in the expressive voting model as

$$
\operatorname{Pr}\left(v_{t}\right) \equiv \sum_{\omega_{t}} \operatorname{Pr}\left(\omega_{t}\right) \prod_{i=1}^{n}\left[1-\Phi\left(\theta_{i t}\left[s_{i t}^{e x p}-\omega_{t}\right]\right)\right]^{v_{i t}} \Phi\left(\theta_{i t}\left[s_{i t}^{e x p}-\omega_{t}\right]\right)^{1-v_{i t}}
$$

In the strategic voting model, justices care about the ruling of the court. As a result, any justice $i$ then considers the implications of her vote assuming that she is pivotal for the decision. (This supposition is not correct when the justice is not in fact pivotal, but for the same reason these mistakes have no cost for the outcome-oriented justice.) Here, the relevant information for justice $i$ in case $t$ is not only her private information $s_{i t}$, but also the equilibrium information contained in the event that $i$ is pivotal for the court's decision, given the equilibrium strategy profile followed by the remaining justices. Let $\mu_{j t}: \mathbf{R} \rightarrow[0,1]$ denote the strategy of justice $j$ in case $t$, where $\mu_{j t}\left(s_{j t}\right) \equiv \operatorname{Pr}\left(v_{j t}=1 \mid s_{j t}\right)$. Then (1) becomes

$$
\frac{P_{\mu_{-i}}\left(\operatorname{piv}_{i t} \mid \omega_{t}=1\right)}{P_{\mu_{-i}}\left(\operatorname{piv}_{i t} \mid \omega_{t}=0\right)} \frac{\phi\left(\theta_{i t}\left[s_{i t}-1\right]\right)}{\phi\left(\theta_{i t} s_{i t}\right)} \geq \frac{\pi_{i t}}{1-\pi_{i t}} \frac{1-\rho_{t}}{\rho_{t}}
$$

As before, the MLRP implies that $i$ 's best response to any strategy $\mu_{-i, t}$ of the remaining justices is a cutoff strategy, such that $i$ rules in favor of the Plaintiff $\left(\mu_{i, t}\left(s_{i t}\right)=\right.$ 1 ) if $s_{i t}$ satisfies (3), and in favor of the Defendant $\left(\mu_{i t}\left(s_{i t}\right)=0\right)$ otherwise. This in turn implies that all responsive equilibria are cutoff equilibria; i.e., that any equilibrium is characterized by cutpoints $s_{i t}^{s t}$ for each justice $i=1, \ldots, n$ such that justice $i$ votes against the Defendant if and only if $s_{i t} \geq s_{i t}^{s t}$. Now, given cutoff strategies, $\operatorname{Pr}\left(v_{i t}=\right.$

\footnotetext{
${ }^{15}$ In our setting, justices share common priors, but their ideological biases are captured by the $\pi_{i t}$ parameters. See Froeb and Kobayashi (1996) for a model where justices' biases are manifested in their priors.
} 
$\left.1 \mid \omega_{t}\right)=\int \mu_{i t}(s) \phi\left(\theta_{i t}\left[s-\omega_{t}\right]\right) d s=\left[1-\Phi\left(\theta_{i t}\left[s_{i t}^{s t}-\omega_{t}\right]\right)\right]$. Therefore from (3), and letting

$\mathcal{C}_{R-1}^{i}$ denote the set of coalitions $C \subset N \backslash i$ with $R-1$ members, $\left\{s_{i t}^{s t}\right\}_{i=1}^{n}$ is given by the $n$ equations

$$
\frac{\sum_{C \in \mathcal{C}_{R-1}}\left(\prod_{j \in C}\left[1-\Phi\left(\theta_{j t}\left[s_{j t}^{s t}-1\right]\right)\right]\right)\left(\prod_{j \neq i, j \notin C} \Phi\left(\theta_{j t}\left[s_{j t}^{s t}-1\right]\right)\right)}{\sum_{C \in \mathcal{C}_{R-1}}\left(\prod_{j \in C}\left[1-\Phi\left(\theta_{j t} s_{j t}^{s t}\right)\right]\right)\left(\prod_{j \neq i, j \notin C} \Phi\left(\theta_{j t} s_{j t}^{s t}\right)\right)} \frac{\phi\left(\theta_{i t}\left[s_{i t}^{s t}-1\right]\right)}{\phi\left(\theta_{i t} s_{i t}^{s t}\right)}=\frac{\pi_{i t}}{1-\pi_{i t}} \frac{1-\rho_{t}}{\rho_{t}}
$$

The cutpoints $\left\{s_{i t}^{s t}\right\}$ completely characterize behavior in any such equilibrium. Given $\left\{s_{i t}^{s t}\right\}$, we can write the likelihood of the justices' votes in case $t$ in the strategic voting case as

$$
\operatorname{Pr}\left(v_{t}\right) \equiv \sum_{\omega_{t}} \operatorname{Pr}\left(\omega_{t}\right) \prod_{i=1}^{n}\left[1-\Phi\left(\theta_{i t}\left[s_{i t}^{s t}-\omega_{t}\right]\right)\right]^{v_{i t}} \Phi\left(\theta_{i t}\left[s_{i t}^{s t}-\omega_{t}\right]\right)^{1-v_{i t}}
$$

The likelihood functions for the expressive and the strategic models (Eqs. 2,5) are almost identical, except for the cutoff points: $s^{\exp }$ for the expressive model, and $s^{s t}$ for the strategic model. ${ }^{16}$

\section{Estimation}

In this section we describe the estimation procedure. To simplify the exposition, we begin with the simplest scenario in which all cases are assumed to be homogeneous, in the sense that all the parameters of the model, $\left\{\left(\theta_{i}, \pi_{i}\right)\right\}_{i=1}^{n}$, as well as $\rho$, are assumed to be identical across cases. This allows us to introduce the key ideas in a simplified setting. We then extend the analysis to the general case in which types and priors vary across cases, depending on case-specific covariates $X_{t}$. This general framework is the one we use in our actual empirical work.

Our estimation procedure has two parts, which we describe in order.

Estimation: First step. We introduce the following notation:

\footnotetext{
${ }^{16}$ We argued that any equilibrium in the expressive and strategic voting models must be in cutoff strategies. In the strategic voting model, however, it is possible that equilibrium is not unique; i.e., that given a prior $\rho$ and types $\left(\theta_{i}, \pi_{i}\right)$ for $i=1, \ldots, n$, there is more than one vector of cutpoints $s^{s t}$ solving (4). Here we assume that if there are multiple equilibria, justices consistently play the same equilibrium whenever the characteristics of the problem are unchanged. It should be noted, however, that in the estimation, for any vector of conditional voting probabilities in the first stage (see Section 4 ), we recover the types $\left(\theta_{i}, \pi_{i}\right)$ uniquely.
} 


$$
\begin{aligned}
& \text { Priors: } \quad \rho \equiv \operatorname{Pr}\left(\omega_{t}=1\right) \quad \text { Voting Probs.: } \quad \gamma_{i, 1} \equiv \operatorname{Pr}\left(v_{i t}=1 \mid \omega_{t}=1\right) \\
& 1-\rho=\operatorname{Pr}\left(\omega_{t}=0\right) \quad \gamma_{i, 0} \equiv \operatorname{Pr}\left(v_{i t}=1 \mid \omega_{t}=0\right)
\end{aligned}
$$

Given this notation, the first-step estimation problem (in both the expressive as well as the strategic case) is to maximize the following reduced-form likelihood function for the votes:

$$
\begin{aligned}
\max _{\left\{\gamma_{i, 1}, \gamma_{i, 0}\right\}_{i=1}^{n}, \rho} \operatorname{Pr}\left(v_{t}\right) & =\rho \prod_{i=1}^{n}\left[\gamma_{i, 1}^{v_{i t}}\left(1-\gamma_{i, 1}\right)^{1-v_{i t}}\right]+(1-\rho) \prod_{i=1}^{n}\left[\gamma_{i, 0}^{v_{i t}}\left(1-\gamma_{i, 0}\right)^{1-v_{i t}}\right] \\
\text { s.t. } \gamma_{i, 1} & \geq \gamma_{i, 0}, \quad \forall i .
\end{aligned}
$$

Conditional on the state $\omega_{t}$, the individual votes $v_{i t}$ are independent across the justices $i$. Thus, the vector of votes $v_{t}$ follows a multivariate mixture distribution, with mixing probability $\rho$.

Second step. Using the estimates of the two justice-specific vote probabilities $\hat{\gamma}_{i, 1}$ and $\hat{\gamma}_{i, 0}$, from the first step, we recover the two structural parameters, $\pi_{i}$ and $\theta_{i}$, for each justice $i$. Recall our earlier assumptions that justice $i$ 's private information is $s_{i t}=$ $\omega_{t}+\frac{1}{\theta_{i}} \varepsilon_{i t}$, with $\varepsilon_{i t} \sim \mathcal{N}(0,1)$. Then $\left.\gamma_{i, 1} \equiv 1-\Phi\left(\theta_{i}\left[s_{i}^{*}-1\right]\right)\right)$ and $\gamma_{i, 0} \equiv\left(1-\Phi\left(\theta_{i} s_{i}^{*}\right)\right)$. Solving these equations for $\theta_{i}$ and $s_{i}^{*}$ given $\hat{\gamma}_{i, 1}$ and $\hat{\gamma}_{i, 0}$ (and substituting $\Phi^{-1}\left(\gamma_{i, 1}\right)=$ $\left.-\Phi^{-1}\left(1-\gamma_{i, 1}\right)\right)$ gives ${ }^{17}$

$$
\hat{\theta}_{i}=\Phi^{-1}\left(1-\hat{\gamma}_{i, 0}\right)-\Phi^{-1}\left(1-\hat{\gamma}_{i, 1}\right) ; \quad \hat{s}_{i}=\frac{\Phi^{-1}\left(1-\hat{\gamma}_{i, 0}\right)}{\Phi^{-1}\left(1-\hat{\gamma}_{i, 0}\right)+\Phi^{-1}\left(\hat{\gamma}_{i, 1}\right)}
$$

Note that the estimate of $\hat{\theta}_{i}$, the precision of $i$ 's information, is given by the difference between the conditional probabilities of voting in favor of the Plaintiff when the law favors the Plaintiff $(\omega=1)$ and when the law favors the Defendant $(\omega=0)$. This implies that precision is increasing in the probability of correctly ruling in favor of the Plaintiff $\left(\gamma_{i, 1}\right)$, and decreasing in $\gamma_{i, 0}$, which is the probability of incorrectly ruling against the defendant. This is very intuitive in light of the theoretical model.

The estimate of the equilibrium cutpoint, instead, is a decreasing function of the ratio between $\Phi^{-1}\left(\hat{\gamma}_{i, 1}\right)$ and $\Phi^{-1}\left(1-\hat{\gamma}_{i, 0}\right)$. Thus $\hat{s}_{i}$ is (roughly) decreasing in the ratio of the probability of voting correctly in favor of the Plaintiff $\left(\gamma_{i, 1}\right)$ relative to the probability of correctly voting in favor of the Defendant $\left(1-\gamma_{i, 0}\right)$. When this ratio is large, for instance - indicating a bias towards the plaintiff - the cutpoint $\hat{s}_{i}$ will be small, implying that the justice requires a low informational threshold to vote in favor of the plaintiff.

\footnotetext{
${ }^{17}$ Note that for each justice, we use the estimates of $\gamma_{i, 0}, \gamma_{i, 1}$ to recover the two quantities $\theta_{i}$ and $s_{i}$. For this reason, we consider a one-parameter specification of the information structure; with additional parameters, we might not have identification.
} 
In order to recover the bias parameter $\pi_{i}$, we use the equilibrium voting condition, which differs between the expressive and strategic models. In the case of the expressive voting model, this is given by

$$
\frac{\phi\left(\theta_{i}\left[\hat{s}_{i}-1\right]\right)}{\phi\left(\theta_{i} \hat{s}_{i}\right)}=\frac{\hat{\pi}_{i}^{e x p}}{1-\hat{\pi}_{i}^{e x p}} \frac{1-\hat{\rho}}{\hat{\rho}}
$$

while in the strategic voting model this is given by

$$
\left[\frac{1-\Phi\left(\theta_{i}\left[\hat{s}_{i}-1\right]\right)}{1-\Phi\left(\theta_{i} \hat{s}_{i}\right)}\right]^{R-1}\left[\frac{\Phi\left(\theta_{i}\left[\hat{s}_{i}-1\right]\right)}{\Phi\left(\theta_{i} \hat{s}_{i}\right)}\right]^{n-R} \frac{\phi\left(\theta_{i}\left[\hat{s}_{i}-1\right]\right)}{\phi\left(\theta_{i} \hat{s}_{i}\right)}=\frac{\hat{\pi}_{i}^{s t}}{1-\hat{\pi}_{i}^{s t}} \frac{1-\hat{\rho}}{\hat{\rho}}
$$

For both models, plugging in our estimates of $\theta_{i}$ and $\hat{s}_{i}$ into the appropriate equilibrium condition allows us to recover estimates of $\hat{\pi}_{i}^{\exp }$ and $\hat{\pi}_{i}^{s t}$ for the expressive and strategic models, respectively.

Note that, in recovering $\theta_{i}$, it was not necessary to specify whether justices vote expressively or strategically. An assumption regarding strategic or expressive voting is required only for recovering $\pi_{i}$. This distinction between $\theta_{i}$ and $\pi_{i}$ is a remarkable property of this problem. It implies that the precision estimate is independent of whether justices care about the court ruling or about their own vote being correct, and therefore of whether justices use the information contained in the event of them being pivotal or simply best respond to their own private information.

Accommodating Case and Justice Heterogeneity. While our foregoing discussion assumed that all cases are homogeneous, our empirical model accommodates case-level heterogeneity by allowing the reduced-form parameters of the model - which are recovered in the first step of the estimation procedure - to depend quite flexibly on observable characteristics $X_{t}$. Specifically, we parameterize justices' priors in case $t, \rho_{t} \equiv \operatorname{Pr}\left(\omega_{t}=1\right)$, as a logit probability which depends on the characteristics $X_{t}$ :

$$
\rho\left(X_{t} ; \beta\right) \equiv \frac{\exp \left(X_{t}^{\prime} \beta\right)}{1+\exp \left(X_{t}^{\prime} \beta\right)}, \quad \in[0,1]
$$

Once the prior probability $\rho_{t}$ varies across cases, so will the equilibrium strategies $s_{i t}^{*}$, and hence so will the justice-specific conditional probabilities of ruling against the Defendant $\gamma_{i t, 1}$ and $\gamma_{i t, 0}$.

Accordingly, we also parameterize these probabilities to depend upon $X_{t}$ (covariates for case $t$ ) and $Z_{i}$ (covariates for justice $i$ ) in the following way, which also restricts $\gamma_{i, t, 1} \geq \gamma_{i, t, 0}$, for all $X_{t}$ :

$$
\begin{aligned}
\gamma_{i, 0}(\zeta, \eta) & =\frac{\exp \left(Z_{i}^{\prime} \zeta+X_{t}^{\prime} \eta\right)}{1+\exp \left(Z_{i}^{\prime} \zeta+X_{t}^{\prime} \eta\right)}, \quad \in[0,1] \\
\gamma_{i, 1}(\zeta, \eta, \alpha, \delta) & =\frac{\gamma_{i, 0}+\exp \left(Z_{i}^{\prime} \alpha+X_{t}^{\prime} \delta\right)}{1+\exp \left(Z_{i}^{\prime} \alpha+X_{t}^{\prime} \delta\right)}, \quad \in\left[\gamma_{i, 0}(\zeta, \eta), 1\right] .
\end{aligned}
$$


In the first stage, we estimate the parameters $(\beta, \delta, \eta)$ as well as the justice-specific variables $\left(\alpha_{i}, \zeta_{i}\right)$ for $i=1, \ldots, n$. For this, we maximize the following likelihood function

$$
\begin{gathered}
\max _{\alpha, \beta, \zeta, \eta, \delta} \sum_{t} \log \left[\rho\left(X_{t} ; \beta\right) \cdot \prod_{i=1}^{n}\left\{\gamma_{i, 1}(\zeta, \eta, \alpha, \delta)^{v_{i t}}\left(1-\gamma_{i, 1}(\zeta, \eta, \alpha, \delta)\right)^{1-v_{i t}}\right\}\right. \\
\left.+\left(1-\rho\left(X_{t} ; \beta\right)\right) \cdot \prod_{i=1}^{n}\left\{\gamma_{i, 0}(\zeta, \eta)^{v_{i t}}\left(1-\gamma_{i, 0}(\zeta, \eta)\right)^{1-v_{i t}}\right\}\right] .
\end{gathered}
$$

For the second stage, we use the predicted values of $\gamma_{i, t, 1}$ and $\gamma_{i, t, 0}$ to recover case and justice specific values of $\theta_{i t}$ and $s_{i t}^{*}$, using the equations in (7). We can then compute the bias estimates solving the $n$ equations (4) for the strategic voting model, or (1) (with equality) for the expressive voting model. Note that, when the voting probabilities $\gamma_{i .0}$ and $\gamma_{i, 1}$ are case-specific and depend on the covariates $X$ and $Z$, then so will the model parameters $\theta$ and $\pi$.

Identification. Clearly, identification of model parameters hinges on the identification of the reduced-form parameters from the first-stage MLE. This in turns relies crucially on the mixture structure of the votes, which are unconditionally dependent due to the unobserved state $\omega_{t}$. Specifically, consider a state supreme court with $n=9$ justices (such as Texas). In this case, the vote vector $v_{t}$ can take $2^{9}$ values, and with a large enough dataset, it is possible to estimate the probability that $v_{t}$ takes each of these values by the empirical frequency. On the other hand, there are only 19 parameters (18 vote probabilities, and $\rho$ ) to estimate, thus satisfying a necessary condition for identification. ${ }^{18}$

At a more intuitive level, the key for identification is that the common value induces a correlation of votes in equilibrium: all justices tend to receive larger signals when the law favors the Plaintiff, and all justices tend to receive smaller signals when the law favors the Defendant.

Suppose first that cases are homogeneous, so that justices' types and prior are invariant across cases. If justices' quality of information were large relative to their bias, and the prior relatively uninformative (say $\pi_{i} \approx 1 / 2$ for all $i$ and $\rho \approx 1 / 2$ ), the court would "flip-flop" evenly between unanimous pro-defendant and pro-plaintiff decisions. Now suppose that instead $\rho \approx 2 / 3$. Since in this case the law favors the Plaintiff more frequently, justices will tend to receive large signals more frequently (moreover, to compensate for the larger prior, justices will also use strategies that are more favorable for the Plaintiff). As a result, the majority of the court would rule for the Plaintiff more often than before. This illustrates the first intuition: the frequency in which the majority

\footnotetext{
18 Moreover, the inequality $\gamma_{i, 1}>\gamma_{i, 0}$, which is implied by the monotone likelihood ratio property, is crucial for identification: without this assumption, the voting probabilities would only be identified up to an arbitrary classification of $\omega_{t}$. This inequality resolves this classification problem by setting $\gamma_{i, 1}$ $\left(\gamma_{i, 0}\right)$ equal to the maximum (minimum) of the two identified voting probabilities. For more details, see Hall and Zhou (2003) or the discussion in Iaryczower and Shum (2009).
} 
decision favors the Plaintiff tracks the prior $\rho$ : a larger frequency corresponds to a larger estimated prior $\rho$.

Now suppose that we change the bias of one justice $i$ in our previous example so that her bias is large relative to the quality of her information. Then while all other justices will alternate between sometimes finding for the Plaintiff and sometimes for the Defendant, $i$ will stay put in one decision. This illustrates the second principle at work: absence of variability in individual decisions signals large bias. Finally, return to the previous example in which all justices are moderate. As we pointed out before, if the quality of information is sufficiently high for all justices, then we would expect these to be unanimous votes. But as the quality of information of some justices is lower, these justices would disagree with the majority more often. This suggests the third principle: justices with variable voting records who tend to be in the minority are associated with a low quality of information.

Now, as it is, this identification scheme appears to penalize "maverick" justices who go against the grain by assigning them a low precision parameter. However, in the empirical work, we control for many case-specific covariates, and take into account inherent differences among justices due to political ideology, judicial experience, etc. Therefore, justices with low $\theta$ 's are those who have attributes that characterize justices who vote inconsistently, even after taking characteristics of the case into account: these are not maverick justices, but erratic ones.

\section{Bureaucrats and Politicians}

Having characterized equilibrium behavior (Section 3) and having described our estimation procedure (Section 4), we can now begin to uncover the differences in type and performance of bureaucrats and politicians. In order to do so, we apply our method to decisions on criminal cases by US states' Supreme Courts. The variability in selection and retention methods across states and the common task across courts (after controlling for case-specific heterogeneity) allows us to pin down the selection and incentive effects of institutions on justices' unobservable types.

\subsection{Data and Specification}

The data for this project has primarily been collected from the State Court Data Project (Brace, Langer, and Hall (2000)), with additional information obtained from the Court Statistics Project at the National Center for State Courts, Marquis' Who's Who, and the updated version of Berry, Ringquist, Fording, and Hanson (1998). The State Court Data Project (SCDP) provides a detailed compilation of data for state Supreme Court cases in all 50 states of the United States during the years 1995 through 1998. The database contains a case-level dataset that describe the particulars of each case during 
this time frame, including the decision of each justice of the relevant court. The SCDP also includes a justice-level dataset, that provides data for each of the 520 justices that served on some court during the period observed, including whether the justice was elected or appointed, and whether the justice served for life or faced either reelection or reappointment to the bench. Marquis' Who's Who provided additional biographical information on each justice.

The courts themselves are described in depth in the Court Statistics Project (CSP), which collects data related to the administrative and legal structure of the state Courts in the United States. The basic layout shared across every state includes at least one trial court, one or more appeals courts, and a court of last resort (generally the Supreme Court). Exceptions to the basic design first include New York, in which the Supreme Court acts as an appeals court and the Court of Appeals acts as the court of last resort, and second, Oklahoma, where there are two courts of last resort dedicated to criminal and civil cases, respectively. For the purposes of this paper, the term "Supreme Court" refers to the court of last resort as it pertains to a given case. Furthermore, while cases may originate in the trial court and move through appeals to the Supreme Court, there are many cases for which the various Supreme Courts have original jurisdiction.

Within our data, we retained those cases that were complete in their information and in which the justices sat en banc. ${ }^{19}$ This left a total of 5958 criminal cases across the fifty states. We then pool the data across all natural courts according to the following specification.

As case-specific covariates, we included basic information about the case, the parties involved, and the legal issue under consideration. These include the manner in which the State Supreme Court takes jurisdiction (Original, Appeal or Habeas Corpus), the type (whether Person, Business, or Government) of Plaintiff and Defendant, the class of legal issues under consideration (issues of evidence, sentencing and jury instruction, and others), and whether a formal opinion was issued with the case as opposed to a per curiam opinion. It is possible that courts in some states might have a more difficult task ahead of them than others as a result of differences in the mix of cases varying in complexity. These differences might be particularly relevant between murder cases and lesser offenses, and for cases involving constitutional challenges. To account for this possibility, we include as an additional covariate whether the original crime considered was murder or not, as well as whether the death penalty was imposed by lower courts or not. We also include whether the case involved a challenge of a law based on the US or State Constitutions, and the number of legal issues considered by the supreme court in each case. Table 7 in the Appendix summarizes the case-specific data, including the proportion of unanimous and minimal winning votes in each state. While a majority of

\footnotetext{
${ }^{19}$ Note that the equilibrium cutpoint of each justice will be different for each different composition of the voting members of the court, implying different conditional probabilities of ruling in favor of the Plaintiff in each state for each configuration of voting members, even fixing the covariates $X_{t}$. Including only the votes in which all justices vote therefore dramatically reduces the number of parameters to be estimated. This still leaves a significant number of cases in the sample (see Table 7).
} 
cases are decided by unanimous verdict, there is also a sizable fraction of non-unanimous verdicts. Moreover, there is, on average, a smaller proportion of unanimous verdicts in courts composed of elected judges (69\% of cases), than those composed of appointed judges (over $80 \%$ of cases), a pattern which is somewhat at odds with the Visser and Swank (2007) model, where justices signal only ability, but not bias.

As justice-specific covariates we include three classes of variables, which we call experience variables, institutional variables, and context variables. Experience variables include the number of years of prior judicial experience, whether each justice had prior political experience or not, and the number of years serving in the state supreme court. Institutional variables describe the selection and retention methods in the state in which the justice serves. While this has considerable variability across states in the detailed specification, we summarize this information in whether the justice was elected or appointed, and in this case, whether she was appointed for life by elected officials, appointed for one term by elected officials with a possible reappointment by the same elected officials, or appointed for one term by elected officials with a possible reappointment depending on an up-or-down decision by voters in a retention election. ${ }^{20}$ Context variables include Brace, Langer, and Hall (2000)'s party-adjusted judicial ideology (PAJID) score for each Justice at the time of appointment (capturing selection effects) and for each case, the interaction of the institutional variables with the (updated version of) Berry et al's citizen (CIT) and government (GOV) ideology (Berry, Ringquist, Fording, and Hanson (1998)) for the relevant state in the year in which the decision was made (capturing incentive effects). The justice-specific data is summarized in Table 8 in the Appendix.

\subsection{First Stage Coefficients and a First Look at Deep Parame- ters}

This section has two purposes. We begin by discussing the first-stage estimates, focusing on the statistical - as opposed to economic or substantive - significance of the variables of interest. We then present a full example of our second stage estimates to aid the interpretation of the general results. We leave the discussion of the general substantive results and the "economic" significance of covariates for the next section.

Table 1 presents the "first stage" MLE estimates of the coefficients of the common prior function $\rho\left(X_{t}\right)$, and of the state-contingent probabilities of ruling against the Defendant $\gamma_{0}\left(X_{t}, Z_{i t}\right)$ and $\gamma_{1}\left(X_{t}, Z_{i t}\right)$.

[Table 1 about here]

\footnotetext{
${ }^{20}$ There is further variability within these classes. In all states in which justices are originally appointed and later face a retention election, the appointment is made by the Governor from nominees selected by a nominating commission. However, the term of the appointments can vary (typically between one and three years in the original term, between six and ten years if retained). In other states, the Governor's appointment requires the confirmation Senate, and in others the appointment is a legislative action. Terms also vary. For more detail, see the website of the American Judicature Society, at http://www.judicialselection.us.
} 
First note that all but one of the case-specific covariates have a statistically significant effect on either justices' prior belief about the case, or their conditional probability of ruling in favor of the Plaintiff in each state. ${ }^{21}$ This is important in that it suggests that our case-specific covariates are allowing us to capture significant variation among states that is due to heterogeneity in case-selection across states.

Consider now the central question of interest here: do political institutions have an effect on justices' bias and quality of information? If this were the case, political institutions would have an effect on justices' equilibrium conditional voting probabilities. We separate the discussion about the results in Table 1 into selection and incentive effects.

We begin with selection effects. Consider first PAJID, Brace et al's party-adjusted judicial ideology scores at the time of appointment. Recall that by construction, this variable captures the political "preferences" of the principal that is relevant to the selection of each justice, be it voters or elected officials. As we can see in the table, PAJID has a statistically significant effect on type, through the state-contingent probabilities of ruling against the Defendant. PAJID captures at least part of the selection effect. Now, if different institutional variables have a systematic effect on justices' type in addition to that induced by the preferences of the principal selecting individuals to the court (as measured by PAJID) then their direct effect (unaffected by context variables at the time of decision) should also capture a selection effect. The results suggest that this is in fact the case: justices in different institutional classes have statistically significant differences in their conditional voting probabilities even after controlling for variation in the context variables describing the attitudes of the voters and elected politicians. Finally for selection components, note that all the experience variables (judicial experience, political experience, and experience in the court) have a statistically significant effect on the state-contingent probabilities of ruling against the Defendant.

Consider next incentive effects. These are captured here by the interaction of the institutional variables with the context variables at the time of the decision. In fact, note that as would be expected, the context variables CIT and GOV only have non-zero effect when interacted with the institutional variables. Next, note that the measure of citizens' ideology CIT is relevant for elected justices, but does not have a statistically significant effect on the conditional voting probabilities of non-elected justices (of any class). This result is consistent with the predictions of the literature, and also with the findings of previous applied research (see Section 2). It also suggests, in particular, that up-ordown retention elections are a poor channel for the expression of citizens' preferences. In regards with the GOV measure of the ideology of elected officials, we find that - as one would expect - GOV has a statistically significant effect on the conditional voting probabilities of appointed justices that are to face political reappointment, but does not have a corresponding effect on the behavior justices appointed for life. The only somewhat unexpected result is that GOV also has a statistically significant effect on the conditional

\footnotetext{
${ }^{21}$ The sole exception here is whether the case was one in which the court had Original jurisdiction, which is statistically undistinguishable from cases of Habeas Corpus. Instead, cases in which the Court acquired jurisdiction from an appeal are statistically significantly different than these base cases.
} 
voting probabilities of elected justices. However, this result would hardly constitute an anomaly, as it could indicate that elected officials might be influential (through funding or campaigning) in the electoral outcomes of judicial elections.

All in all, the results of the first-stage are very compelling, and provide strong evidence of a (statistically) significant effect of political institutions on justices' prior beliefs and their equilibrium conditional voting probabilities, due to both selection effects (uniformly) and incentive effects (for justices who are either elected, or face a political reappointment).

Deep Parameters' Estimates: an Example. Given the first stage coefficients we can compute, for any case $t$ with characteristics $X_{t}$, the common prior $\rho_{t}=\rho\left(X_{t}\right)$, as well as the conditional probabilities $\gamma_{i, t, 0}=\gamma_{0}\left(X_{t}, Z_{i t}\right)$ and $\gamma_{i, t, 1}=\gamma_{1}\left(X_{t}, Z_{i t}\right)$ that a Justice with characteristics $Z_{i t}$ in case $t$ rules for the Plaintiff when the law favors the Plaintiff and when the law favors the Defendant. For a given court composition $C$, we can then use the predicted values of $\gamma_{i, t, 1}$ and $\gamma_{i, t, 0}$ for each member $i$ of $C$ to recover the case and justice specific values of $s_{i t}^{*}$, and the "deep parameters" $\theta_{i t}$ and $\pi_{i t}$.

To describe the main results we fix all case-specific covariates at the state-specific sample means, and use the justice-specific covariates of the justices sitting in each state's Supreme Court. In particular, when there is more than one court composition (natural court) per state in the data (as it usually is the case), we report results for the largest natural court (LNC); i.e. the court that decided more cases than any other natural court of the same state. We begin by presenting the complete set of estimates for three sample courts - the LNCs of California, Connecticut and Texas - to aid the interpretation of the general results. (For simplicity of exposition, in Table 2, we present point estimates only. Table 6 in the Appendix provides standard errors of all "second-stage" estimates presented in Table 2.)

\section{[Table 2 about here]}

In the table, we indicate the MLE estimate of the common prior probability that the law favors the Plaintiff in each state. In these examples, the prior probability of the law favoring the Plaintiff is $\rho=0.67$ for California, $\rho=0.54$ for Connecticut, and $\rho=0.61$ for Texas. This indicates that given their specific case selection, in all three states the common prior belief favors the Plaintiff. This is a moderate effect for Connecticut, where the prior is close to the uninformative prior of $\rho=1 / 2$, but more significant for Texas and California.

The first two columns present the MLE estimates of the probability that justice $i$ rules in favor of the Plaintiff when the law favors the Defendant $\left(\gamma_{i t 0}\right)$ and when the law favors the Plaintiff $\left(\gamma_{i t 1}\right)$. Thus, for example, justice Marvin Baxter of California had a probability of $\gamma_{i t 1}=0.93$ of (correctly) ruling in favor of the Plaintiff when the law favors the Plaintiff, and a probability of $1-\gamma_{i t 0}=1-0.15=0.85$ of (correctly) ruling in favor of the Defendant when the law favors the Defendant. Similarly, justice Robert 
Berdon of Connecticut had a probability of $\gamma_{i t 1}=0.97$ of (correctly) ruling in favor of the Plaintiff when the law favors the Plaintiff, and a probability of $1-\gamma_{i t 0}=1-0.03=0.97$ of (correctly) ruling in favor of the Defendant when the law favors the Defendant.

Column 3 presents the estimate of the quality of the information of each justice. As we pointed out earlier, this estimate is an increasing function of the difference between the probability that justice $i$ rules in favor of the Plaintiff when the law favors the Plaintiff and when the law favors the Defendant. The higher quality-of-information estimate for justice Berdon (3.70) vis a vis that of justice Baxter (2.51), for example, reflects both a larger probability of (correctly) ruling for the Plaintiff when the law favors the Plaintiff (0.97 vs 0.93 ), and a lower probability of (incorrectly) ruling for the Plaintiff when the law favors the Defendant (0.03 vs 0.15).

Column 4 presents the equilibrium cutpoint. This is the signal threshold $s_{i}^{*}$ such that Justice $i$ votes for the Defendant whenever she observes a signal below $s_{i}^{*}$ and for the Plaintiff otherwise. Thus for example while justice Berdon would vote for the Defendant after observing a signal below $s_{B E R}^{*}=0.49$, it would take a signal below $s_{B A X}^{*}=0.41$ for justice Baxter, and a signal below $s_{B A I}^{*}=0.38$ for justice Charles Baird from Texas to rule in favor of the Defendant. As we noted before, the cutpoint estimate for each justice $i$ is a decreasing function of the ratio between $\Phi^{-1}\left(\hat{\gamma}_{1}\right)$ and $\Phi^{-1}\left(1-\hat{\gamma}_{0}\right)$. To illustrate this in the context of our example, this ratio is $1.03=1.88 / 1.82$ for justice Berdon, $1.46=1.48 / 1.02$ for justice Baxter, and $1.64=1.56 / 0.95$ for justice Baird.

Given the estimates, we can also understand the ordering of equilibrium cutpoints in terms of the case specific prior and the justice/case specific type of each justice. First, for Berdon, Baxter and Baird, the prior stacks the deck in favor of the Plaintiff, and contributes to a larger equilibrium cutpoint for all justices (more so for Baxter and Baird, moderately so for Berdon). The second factor at play here is the bias of the justice in question (and in the strategic voting model, also of the remaining justices in the court, through their equilibrium strategy $s_{-i}^{*}$ ). The justices' bias are shown in columns 5 and 6 in the table. Note that in both the strategic and the expressive voting models, justice Baird of Texas is more inclined to rule in favor of the Plaintiff than justice Berdon of Connecticut, and him in turn more than justice Baxter of California. In the expressive voting model, for example, for the type of case each of these justices "typically" faces, justice Baird requires less evidence (a belief of at least $\pi_{B A I}^{\exp }=042$ that the law favors the Plaintiff) to rule in favor of the Plaintiff than justice Berdon $\left(\pi_{B E R}^{e x p}=0.51\right)$ and justice Baxter $\left(\pi_{B A X}^{e x p}=0.53\right)$. The third factor is the quality of information of each justice. A larger quality of information $\theta_{i}$ pushes $i$ 's cutpoints towards $1 / 2$, the threshold of an "unbiased" justice. This explains why in equilibrium Berdon uses a "much more moderate" strategy than Baxter in both the strategic and the expressive voting models.

Column 7 indicates for each justice $i$, the ratio of the probability that $i$ is pivotal when other justices follow their equilibrium strategies and the law favors the Plaintiff and the corresponding probability when the law favors the defendant. We can see in the Table that in equilibrium, in California, Connecticut and Texas the event of being 
pivotal conveys favorable information for the Defendant. This is why in all three states justices are more biased in favor of the Plaintiff in the strategic voting model than in the expressive voting model: in order to be consistent with the same cutpoint as in the expressive voting model, a justice has to be more "biased" towards the Plaintiff (Defendant) whenever the equilibrium information favors the Defendant (Plaintiff).

Given these estimates, we can compute a measure of the value of information in the court, as introduced in Iaryczower and Shum (2009). The measure, FLEX, is the probability that justice $i$ votes differently than what she would have voted for in the absence of her private case information:

$$
F L E X_{i t}= \begin{cases}\rho_{t} \Phi\left(\theta_{i t}\left[s_{i t}^{*}-1\right]\right)+\left(1-\rho_{t}\right) \Phi\left(\theta_{i t} s_{i t}^{*}\right) & \text { if } \rho_{t} \geq \pi_{i t} \\ \rho_{t}\left[1-\Phi\left(\theta_{i t}\left[s_{i t}^{*}-1\right]\right)\right]+\left(1-\rho_{t}\right)\left[1-\Phi\left(\theta_{i t} s_{i t}^{*}\right)\right] & \text { if } \rho_{t}<\pi_{i t} .\end{cases}
$$

Note that FLEX is bounded between zero and one, and takes a value of zero for individuals with extremely large biases either for the Plaintiff $(\pi \rightarrow 0)$ or for the Defendant $(\pi \rightarrow 1) .{ }^{22}$ Note, moreover, that FLEX scores integrate information about the quality of information and bias of each justice. The FLEX scores for the expressive and strategic voting models are presented in columns 8 and 9 of the table. Consistent with our previous remarks, the value of information in the court is on average higher for justices in Connecticut than for justices in California and Texas.

\subsection{Main Results}

We can now begin to answer the questions that we laid out at the beginning of the paper. Our goal is to understand the differences in type and performance of appointed and elected justices. Does the type of institution used to select and retain justices have a systematic impact on the quality and bias of the individuals serving in the court? Moreover, we seek to shed light on the roles of the selection and incentive effects. Do voters select a different type of justice - more or less biased, better or worst at gathering and processing information relevant to the case -than government officials? Do reelections, retention elections and political reappointment procedures induce justices serving in the court to spend more or less effort to improve their proficiency to deal with the flow of information of each case, or to be more or less responsive to the public? Do voters select a different type of justice - more or less biased, better or worst at gathering and processing

\footnotetext{
${ }^{22}$ Note also that the computation of FLEX for the expressive and strategic voting models differ only in whether we use $\pi_{i}^{e x p}$ or $\pi_{i}^{s t}$ to evaluate whether $\rho \geq \pi_{i}$ or $\rho \leq \pi_{i}$. The reason for this is that the equilibrium cutpoint $s_{i}^{*}$ that is recovered from the data is invariant to whether we use the expressive or strategic voting models. Together with the data, the two models imply the same $s_{i}^{*}$ and $\theta_{i}$, and differ only in the biases $\pi_{i}$ that rationalize these quantities. As a result, in practical terms this means that the expressive and strategic FLEX scores for any given justice and any given realization of the covariates $X_{t}$ are very often identical. If instead we were initially given values of $\left\{\pi_{i}, \theta_{i}\right\}$ and $\rho$, then the two models would imply a different equilibrium cutpoint $s_{i}^{*}$, and FLEX scores in the two models would differ significantly.
} 
information relevant to the case -than government officials? Do reelections, retention elections and political reappointment procedures induce justices serving in the court to spend more or less effort to improve their proficiency to deal with the flow of information associated to each case? Do reelections or retention elections induce justices serving in the court to be more or less responsive to the public?

Table 3 presents the state averages (of the individual estimates for each justice $i$ in the LNC of each state) of the prior probability that the law favors the Plaintiff, the conditional probabilities of voting in favor of the Plaintiff when the law favors the Defendant and the Plaintiff $\left(\gamma_{i, 0}, \gamma_{i, 1}\right)$, the equilibrium strategy cutpoint $s_{i}^{*}$, and the justice type $\left(\theta_{i}, \pi_{i}\right)$. As in Table 2, the estimates for each court are computed here with case-specific variables evaluated at their state-specific sample means, and individual justices evaluated at their own justice-specific variables (i.e., Table 3 presents the averages of the table 2 estimates for each of the fifty state courts). The states are arranged in four groups, according to the broad class of institutions for selection and retention they use. The first is the group of states in which justices are elected in competitive plurality elections. The second group includes states in which justices are originally appointed by elected officials, but face an up-or-down decision by voters in a retention election to retain their position in the court. The third group includes states in which justices are appointed by elected officials, and considered for reappointment after a first term also by elective officials. The fourth group includes states in which justices are appointed by elected officials for life. ${ }^{23}$

\section{[Table 3 about here]}

We pointed out in Section 5.2 that our case-specific covariates have a statistically significant effect on the prior probability that the law favors the Plaintiff. Table 3 shows that they are also substantively significant. The substantial variation in priors across states suggests that we are able to control for what is a significant heterogeneity in case-selection across states. The inclusion of these case-specific variables is important to assure that the remaining variation in types is due to institutional factors and not to unaccounted heterogeneity in the type of cases considered by each court.

Table 3 shows that the different institutions for election and retention of justices have a significant impact on the quality $(\theta)$ and value of information $(F L E X)$ in the court. First, justices that do not face any kind of voter evaluation after being appointed on average have higher quality of information than justices that face either reelection or retention elections. In fact, the information quality for justices appointed for life and justices that are appointed and reappointed is on average $25 \%$ larger than that of justices facing retention elections, and 30\% larger than that of justices that are elected. The effects are substantively and statistically significant.

The institutions of selection and retention of justices also influence justices' predisposition to rule in favor or against the Defendant, as measured by $\pi$. In particular, justices

\footnotetext{
${ }^{23}$ We include New Jersey in this group because upon being reappointed, justices are appointed for life. Illinois, New Mexico and Pennsylvania have up-or-down retention elections for reappointment.
} 
that do not face any kind of voter evaluation after being appointed are on average more biased than those who do (in both the expressive and strategic voting models). However, these differences in bias across voting institutions are less striking than the differences in quality. In the expressive voting model, for example, the average elected justice would rule in favor of the Defendant only if after all information is taken into consideration, the posterior probability that the law favors the Plaintiff is below $E\left[\pi^{\text {exp }} \mid\right.$ elected $]=0.41$. Instead, the average justice appointed subject to a reappointment would rule in favor of the Defendant only if the posterior probability that the law favors the Plaintiff is below $E\left[\pi^{e x p} \mid R e a p p\right]=0.40$, and the average justice appointed for life only if it is below $E\left[\pi^{\text {exp }} \mid\right.$ life $]=0.37$.

The preceding results imply that, in determining the value of information in the court, differences in information quality across institutional environments trump differences in bias. As was the case with the quality of information, FLEX scores are also larger on average the more isolated justices are from voters. The average FLEX score for elected justices $(0.36)$ is lower than that of appointed justices facing retention elections $(0.38)$, this in turn lower than that for appointed justices facing political reappointment (0.39), and this is turn lower than that for justices appointed for life $(0.41)$.

Selection and Incentive Effects \& Case Heterogeneity. In Table 3 we computed the estimated type of justices in different states allowing all case-specific and justicespecific covariates to vary. This is the appropriate exercise to obtain the total effect of political institutions on justices' bias and quality of information. In this section, we complement these results in two ways.

First, it is important to establish that differences in type are not just due to heterogeneity in case-selection across states. Note that since we allow justices' types to vary in response to changes in case-specific covariates, then - even after controlling for variation in our case-specific covariates in the estimation - the previous results reflect differences in case-selection across states. In order to eliminate completely heterogeneity in case-selection, we recompute the types of justices in the LNC of each state fixing case-specific covariates at the national sample mean. In Table 4 (column 2), we report the state averages of the bias and quality of information fixing case-specific covariates at the national sample mean. Comparing these results with our benchmark result (column 1) shows that differences in type persist even after we impose a homogeneous caseload across state courts: the patterns we uncovered in types across institutions are not due to heterogeneous case-selection. The first main message in Table 4 then, is that it is indeed institutions that drive the main results.

Second, note that justices differ not only in the selection and retention methods they face, but also in observable characteristics at the time of their appointment (PAJID, prior judicial and political experience), in their experience in the court at the time of the decision, and in the context they face at the time of the decision (CIT and GOV measures of citizen and government ideology). As a result, Table 3 lumps together the 
impact that institutions have on the bias and information quality of justices through the incentives they provide for individuals to advance their political and judicial careers, with that caused by their systematic effect on the selection of justices of different types. To disentangle these incentive and selection effects, we recompute the type estimates fixing case-specific covariates at the national sample mean and justices' PAJID scores and experience variables (prior political, prior judicial, and in the court) at their average for all justices in LNCs. The residual within-class variation can be attributed to the forward-looking impact of institutions through the incentives they provide justices to advance their political and judicial careers. We report the state averages of the bias and quality of information computed in this way in the third column/s of Table 4.

[Table 4 about here]

The results suggest that incentive effects are mainly circumscribed to elected positions. Consider first non-elected justices facing up-or-down retention elections. Note that fixing PAJID scores and experience among justices eliminates practically all variability in types across justices in this class. Since incentive effects are context specific - and thus state specific as well - this indicates a weak incentive effect for justices facing retention elections. It follows that almost all of the variability in justices' types across states with retention elections for justices can be attributed to heterogeneity in case selection, selection effects (PAJID, judicial and political experience) and differences in experience in the court. A similar conclusion can be drawn for the other classes of appointed justices, although in these cases fixing PAJID scores and experience among justices cannot account for all variability in types within class. $^{24}$

For elected justices, the opposite is true. Note that in columns 1 and 2, the quality of information of elected justices has a similar average and variability than that of non-elected justices facing retention elections. But fixing PAJID scores and experience among elected justices leaves almost all within-group variability in bias and quality of information unaccounted for. This suggests that differences in selection (PAJID, judicial and political experience) and experience in the court have a relatively small impact on the type of elected justices. Thus, as long as our selection and experience variables capture selection effects adequately, the bulk of the variability in types of elected justices must be attributed to incentive effects.

Effectiveness of Bureaucrats and Politicians. Tables 3 and 4 focused on how selection and retention procedures impact justices's bias and quality of information. Ultimately, however, we care about this because of how it impacts on outcomes. In our next results, we switch attention from the type of justices to their performance: is there a systematic difference in the performance of elected and appointed justices? In the context

\footnotetext{
${ }^{24}$ Note however that the incentive effects for this class are also more imprecise, as the context variables are not statistically significant for non-elected justices (see Table 1).
} 
of the common value voting model, a natural measure of performance is the probability of a mistake in the decision of the court. In this section we use the estimated individual conditional voting probabilities to compute this probability.

Fix a court $j$. Note that for any given case characteristics $X$, our first stage estimates provide the probability that a member $i$ of court $j$ votes for the Defendant when the law favors the Plaintiff $1-\gamma_{i, 1}$, and for the Plaintiff when the law favors the Defendant, $\gamma_{i, 0}$ (we drop the obvious dependence on $X$ to simplify notation). For a simple majority rule, we can then use these individual conditional probabilities to compute the probability that court $j$ will rule for the Defendant when the law favors the Plaintiff, $\operatorname{Pr}\left(v_{j}=0 \mid \omega=1\right)$, and for the Plaintiff when the law favors the Defendant, $\operatorname{Pr}\left(v_{j}=1 \mid \omega=0\right){ }^{25}$ Given a prior $\rho_{j}$, we can then compute the total probability of an incorrect ruling for court $j$,

$$
\beta_{j}^{S M}=\rho_{j} \operatorname{Pr}\left(v_{j}=0 \mid \omega=1\right)+\left(1-\rho_{j}\right) \operatorname{Pr}\left(v_{j}=1 \mid \omega=0\right)
$$

Figure 1 shows the probability of an incorrect ruling in each state of nature (a ruling for the Defendant when the Plaintiff should win, and a ruling for the Plaintiff when the Defendant should win) and the ex ante probability of an incorrect ruling of any kind, per state.

[Figure 1 about here]

The total probability of an incorrect ruling $\beta_{j}^{S C}$ (the bars in the figure) ranges from under $0.1 \%$ for the top five states - New York, Connecticut, New Jersey, Rhode Island, and Massachusetts - to between $1.4 \%$ and $4 \%$ for the bottom five states - North Carolina, Georgia, Kentucky, Nevada and Idaho. Thus, even when individual members have a much larger probability of making a wrong decision (see Table 3), the "wisdom of the majority" implies that state supreme courts have a relatively low total error rate.

However, the pattern of mistakes is highly asymmetric. On the one hand, the probability of an incorrect ruling in favor of the Defendant when the Plaintiff should win is very low, with most courts having a negligible probability of a mistake of this kind (the exceptions being Tennessee and Colorado). On the other hand, more than fifteen courts have a probability above $2 \%$ of reaching an incorrect decision in favor of the Plaintiff when the Defendant should win. In fact, this probability is above $4 \%$ for the bottom five courts, and above $6 \%$ for the bottom three.

This asymmetry should come as no surprise given our previous results in Table 3 . Note that in forty three of the fifty states, the mean individual probability of ruling for the Defendant when the Plaintiff should win $\left(1-\gamma_{i, 1}\right)$ is strictly smaller than the mean

\footnotetext{
${ }^{25}$ Letting $\mathcal{C}(k)$ denote the set of coalitions with exactly $k$ members, $\operatorname{Pr}\left(v_{j}=0 \mid \omega=1\right)=$ $\sum_{k=5}^{9} \sum_{C \in \mathcal{C}(k)} \prod_{i \in C}\left(1-\gamma_{i, 1}\right) \prod_{i \notin C} \gamma_{i, 1}$, and $\operatorname{Pr}\left(v_{j}=1 \mid \omega=0\right)=\sum_{k=5}^{9} \sum_{C \in \mathcal{C}(k)} \prod_{i \in C} \gamma_{i, 0} \prod_{i \notin C}(1-$ $\left.\gamma_{i, 0}\right)$.
} 
individual probability of ruling for the Plaintiff when the Defendant should win $\left(\gamma_{i, 0}\right)$, and in only one state (Colorado) the difference is large in size towards the Defendant. In other words, at the individual level, on average, justices make comparatively large mistakes in favor of the Plaintiff. This is particularly true for elected justices, for whom on average $1-\gamma_{i, 1} \approx 4 \%$ and $\gamma_{i, 0} \approx 16 \%$. The steep asymmetry in type I and type II errors implies that almost all of the overall probability of a mistake of any kind is explained by (i) the probability of an incorrect decision in favor of the Plaintiff and (ii) the prior probability $\rho_{j}$ that court $j$ finds itself in the state of nature in which it makes comparatively fewer mistakes.

Aggregating the court effectiveness results by institutional class reinforces the conclusions that we emphasized in the discussion of Table 3. We established there that justices that do not face any kind of voter evaluation after being appointed on average have higher quality of information than justices that face either reelection or retention elections. We also established there that - as a result of the fact that the institutions of selection and retention of justices affect justices' type predominantly through their impact on the quality of information - the same is true for the value of information in the court. The same conclusion follows here. Quality of information, the value of information (FLEX scores), and the effectiveness of the court (the probability of a correct decision) are all larger on average the more shielded from voters justices are. Specifically, justices appointed for life and appointed justices with a political reappointment on average have a lower probability of reaching an incorrect decision $(0.1 \%)$ than justices that are appointed and face retention elections (0.4\%), and than justices that are elected $(0.9 \%)$. The effect is larger when we consider the probability of reaching an incorrect decision in favor of the Plaintiff. In this case, the corresponding probabilities are $0.3 \%$ for justices that are isolated from voters, $1.1 \%$ for justices facing retention elections and $2.6 \%$ for justices facing competitive reelections.

Can Unanimity Rule Improve Performance? A natural question here is how the effectiveness of State Supreme Courts would change if the current method by which they aggregate the votes of its individual members (simple majority rule) were replaced with a different decision-making rule. In particular, because of the asymmetry in the pattern of mistakes in favor of the Plaintiff, it is especially interesting to compare the performance of the courts under the current rules with a counterfactual scenario in which ruling against the Defendant requires the unanimous consent of all members.

To evaluate this, we need to compute the probability of mistakes under unanimity. In the expressive voting model, this is straightforward. Here behavior is unaffected by the aggregation mechanism, and therefore so are the individual strategy cutpoints and conditional probabilities. The only change is in the aggregation rule. Here the probability of the court ruling for the Defendant when the law favors the Plaintiff is $1-\prod_{i=1}^{n_{j}}\left(1-\gamma_{i, 1}\right)$ and the probability of the court ruling for the Plaintiff when the law favors the Defendant is $\prod_{i=1}^{9} \gamma_{i, 0}$. Thus the total probability of an incorrect ruling for the Supreme Court under 
unanimity rule in the expressive voting model is $\beta_{j}^{U, \exp }$

$$
\beta_{j}^{U, \exp }=\rho_{j}\left[1-\prod_{i=1}^{n_{j}}\left(1-\gamma_{i, 1}\right)\right]+\left(1-\rho_{j}\right)\left[\prod_{i=1}^{n_{j}} \gamma_{i, 0}\right]
$$

In the strategic voting model, the computation of the total probability of mistakes under unanimity rule requires an additional step because the aggregation mechanism now clearly affects equilibrium behavior. Thus we cannot use the conditional probabilities of ruling for the Defendant recovered from justices' votes, but rather we must recompute the behavioral probabilities that are consistent with equilibrium behavior under unanimity. Fortunately, this is not difficult to do given our previous results. Given our estimates $\left\{\left(\pi_{i}^{s t}, \theta_{i}\right)\right\}$ we can use Eq. (4) with $R$ to compute the equilibrium strategy cutpoints $s_{i}^{* *}$ consistent with unanimity rule. Given $s^{* *}$, we can then compute $\gamma_{i, 1}^{* *}=1-\Phi\left(\theta_{i}\left[s_{i}^{* *}-1\right]\right)$ and $\gamma_{i, 0}^{* *}=1-\Phi\left(\theta_{i} s_{i}^{* *}\right)$. Then the total probability of an incorrect ruling for the Supreme Court under unanimity rule in the strategic voting model $\beta_{j}^{U \text {,st }}$ is

$$
\beta_{j}^{U, s t}=\rho_{j}\left[1-\prod_{i=1}^{n_{j}}\left(1-\gamma_{i, 1}^{* *}\right)\right]+\left(1-\rho_{j}\right)\left[\prod_{i=1}^{n_{j}} \gamma_{i, 0}^{* *}\right]
$$

Table 5 shows the results per state, grouped as before by class of political institution. The results show that introducing the change to unanimity rule would have major consequences to public outcomes and the effectiveness of the courts.

[Table 5 about here]

Consider first the expressive voting model. If justices care about their own vote only, replacing majority rule by unanimity rule does achieve the purpose of reducing the probability of an incorrect court decision in favor of the Plaintiff (column 4 in the table). On the flip side, this is achieved by dramatically increasing the probability of an incorrect court decision in favor of the Defendant (reaching 33\% for elected justices, and 35\% for non-elected justices facing retention elections).

The strategic voting model also predicts large changes in outcomes as a result of the change in the voting rule. Here, however, the changes occur in the opposite direction. As a result of the move to unanimity, strategic justices who care about the decision of the court would modify their strategy in equilibrium. And because the event of being pivotal (all other $n_{j}-1$ members voting to rule in favor of the Plaintiff) here carries favorable information for the Plaintiff, in equilibrium all justices become harsher against the Defendant (so as to tilt the equilibrium inference in favor of the Defendant; see Feddersen and Pesendorfer (1998)). As a result, the move to unanimity significantly increases the probability of a mistaken decision against the Defendant (reaching a maximum of $21 \%$ for elected justices). 


\section{Conclusion}

What separates bureaucrats from politicians? This fundamental question for representative democracy has three parts. First, do voters select a different type of public official - more or less biased, better or worst at gathering and processing information -than government officials? Second, do reelections induce public officials to improve their proficiency to deal with the flow of information of each decision? Do they induce them to be more responsive to the public? Third, are bureaucrats more effective than politicians?

In order to answer these questions, we need to map institutions to the type of public officials they induce. The difficulty, of course, is that this type is unobservable. The contribution of this paper is to bridge this gap by specifying a decision-making model, and using equilibrium information to recover the unobservable types. The main idea is to exploit the information contained in the joint observation of the votes of members of committees that deal with issues involving both ideological considerations and common values. The underlying common value induces correlation in actions (votes) in equilibrium, which allows us to disentangle bias and quality of information.

We focus on criminal decisions in US states' Supreme Courts. The main results we obtain clarify the trade-offs inherent in choosing between bureaucrats and politicians. First, justices that are shielded from voters' evaluations on average have higher quality of information than justices that face either reelection or retention elections. In fact, the information quality for justices that are shielded from voters' influence (those appointed for life and those appointed and reappointed by elected officials) is on average $25 \%$ larger than that of justices facing retention elections, and 30\% larger than that of justices that are elected. Institutions of selection and retention of justices also affect justices' bias (justices that are not shielded from voters are more moderate on average), but this effect is more modest in magnitude. As a result, differences in information quality across jurisdictions trump differences in bias, and justices who are shielded from voters not only have better information, but are also more likely than elected justices to change their

preconceived opinions about a case, and have a better performance (lower probability of making incorrect decisions) than elected justices.

Finally, we show that while the pattern of mistakes of state supreme courts is highly asymmetric - with the courts making comparatively large mistakes in favor of the Plaintiff - changing the voting rule to a rule more protective of the Defendant would produce major consequences to public outcomes and the effectiveness of the courts. Thus any such change should be considered with great care. 


\section{References}

Alesina, A., And G. Tabellini (2007): "Bureaucrats or politicians? Part I: A Single Policy Task," American Economic Review, 97(1), 169-179.

(2008): "Bureaucrats or politicians? Part II: Multiple Policy Tasks," Journal of Public Economics, 92(3-4), 426-447.

Austen-Smith, D., And J. S. Banks (1996): "Information Aggregation, Rationality, and the Condorcet Jury Theorem," American Political Science Review, 90, 34-45.

Austen-Smith, D., And T. Feddersen (2005): "Deliberation and Voting Rules," In Social Choice and Strategic Decisions: Essays in Honor of Jeffrey S. Banks, pp. 269-316.

- (2006): "Deliberation, Preference Uncertainty, and Voting Rules," American Political Science Review, 100, 209-218.

Banks, J., And R. Sundaram (1998): "Optimal Retention in Agency Problems," Journal of Economic Theory, 82(2), 293-323.

Barro, R. (1973): "The Control of Politicians: an Economic Model," Public Choice, 14(1), $19-42$.

Berry, W., E. Ringquist, R. Fording, and R. Hanson (1998): "Measuring Citizen and Government Ideology in the American States, 1960-93," American Journal of Political Science, 42(1), 327-348.

Besley, T., And A. Case (2003): "Political Institutions and Policy Choices: Evidence from the United States," Journal of Economic Literature, 41(1), 7-73.

Besley, T. J., And A. A. Payne (2005): "Implementation of Anti-Discrimination Policy: Does Judicial Selection Matter?," LSE STICERD Research Paper No. PEPP04.

Besley, T. J., And M. Reynal-Querol (2010): "Do Democracies Select more Educated Leaders?," Working Paper, LSE.

Bonneau, C., And M. Hall (2006): "Does Quality Matter? Challengers in State Supreme Court Elections," American Journal of Political Science, 50(1), 20-33.

Brace, P., And M. Hall (1990): "Neo-institutionalism and Dissent in State Supreme Courts," The Journal of Politics, 52(1), 54-70.

(1997): "The Interplay of Preferences, Case Facts, Context, and Rules in the Politics of Judicial Choice," The Journal of Politics, 59(4), 1206-1231.

Brace, P., And M. G. Hall (1993): "Integrated Models of Judicial Dissent," The Journal of Politics, 55(4), 914-935.

Brace, P., L. Langer, and M. Hall (2000): "Measuring the Preferences of State Supreme Court Judges," The Journal of Politics, 66(2), 387-413. 
Cameron, C. M., And L. A. Kornhauser (2008): "Modeling Collegial Courts (3): Judicial Objectives, Opinion Content, Voting and Adjudication Equilibria," Law \& Economics Research Paper Series, Working Paper No. 08-54.

Canes-Wrone, B., M. Herron, And K. Shotts (2001): "Leadership and Pandering: A Theory of Executive Policymaking," American Journal of Political Science, 45(3), 532-550.

Canes-Wrone, B., And K. Shotts (2007): "When Do Elections Encourage Ideological Rigidity?," American Political Science Review, 101(2), 273-288.

Choi, S. J., G. Gulati, and E. A. Posner (forthcoming): "Professional or Politicians: the Uncertain Empirical Case for an Elected Rather than Appointed Judiciary," Journal of Law, Economics, and Organization.

Clinton, J. D., S. Jackman, And D. Rivers (2004): "The Statistical Analysis of Roll Call Data," American Political Science Review, 55, 355-370.

Clinton, J. D., And A. Meirowitz (2003): "Integrating Voting Theory and Roll Call Analysis: A Framework," Political Analysis, 11, 381-396.

(2004): "Testing Explanations of Strategic Voting in Legislatures: A Reexamination of the Compromise of 1790," American Journal of Political Science, 48(4), 675-689.

CoAte, S., And M. Conlin (2004): "A Group Rule-Utilitarian Approach to Voter Turnout: Theory and Evidence," American Economic Review, 94, 1476-1504.

Conte, S., M. Conlin, And A. Moro (2008): "The performance of pivotal-voter models in small-scale elections: Evidence from Texas liquor referenda," Journal of Public Economics, $92,582-596$.

Coughlan, P. (2000): "In Defense of Unanimous Jury Veredicts: Mistrials, Communication, and Strategic Voting," American Political Science Review, 94, 375-393.

Degan, A., And A. Merlo (2008): "Do Voters Vote Ideologically?," Working Paper, U. Penn.

De Paula, A., And A. Merlo (2009): "Identification and Estimation of Preference Distributions when Voters are Ideological," Working Paper, U. Penn.

Diermeier, D., M. Keane, and A. Merlo (2005): "A Political Economy Model of Congressional Careers," American Economic Review, pp. 347-373.

Doraszelski, U., D. Gerardi, and F. Squintani (2003): "Communication and Voting with Double-Sided Information," Contributions to Theoretical Economics, 3, 1-39.

Duggan, J., And C. Martinelli (2001): "A Bayesian Model of Voting in Juries," Games and Economic Behavior, 37, 259-294.

Feddersen, T., And W. Pesendorfer (1997): "Voting Behavior and Information Aggregation in Elections With Private Information," Econometrica, 65, 1029-1058.

(1998): "Convicting the Innocent: The Inferiority of Unanimous Jury Verdicts under Strategic Voting," American Political Science Review, 92, 23-35. 
Ferejohn, J. (1986): "Incumbent Performance and Electoral Control," Public Choice, 50, $5-25$.

Froeb, L. M., And B. H. Kobayashi (1996): "Naive, Biased, yet Bayesian: Can Juries Interpret Selectively Produced Evidence?," Journal of Law, Economics, and Organization, $12,257-275$.

Gely, R., AND P. SpILler (1990): "A Rational Choice Theory of Supreme Court Statutory Decisions with Applications to the "State Farm" and "Grove City Cases"," Journal of LawEconomics\& Organization, 6(2), 263-300.

Gerardi, D., And L. YARIV (2007): "Deliberative Voting," Journal of Economic Theory, $134,317-338$.

Gordon, S., And G. Huber (2007): "The Effect of Electoral Competitiveness on Incumbent Behavior," Quarterly Journal of Political Science, pp. 107-138.

Hall, P., AND X.-H. Zhou (2003): "Nonparametric Estimation of Component Distributions in a Multivariate Mixture," Annals of Statistics, 31, 201-224.

Hanssen, A. (2000): "Independent Courts and Administrative Agencies: an Empirical Analysis of the States," Journal of Law, Economics and Organization, 16(2), 534-571.

(2004): "Is There a Politically Optimal Level of Judicial Independence?," American Economic Review, 94(3), 712-729.

Heckman, J., And J. J. Snyder (1997): "Linear Probability Models of the Demand for Attributes with an Empirical Application to Estimating the Preferences of Legislators," The RAND Journal of Economics, 28(0), S142-S189, Special Issue in Honor of Richard E. Quandt.

Helmke, G. (2002): "The Logic of Strategic Defection: Court-Executive Relations in Argentina under Dictatorship and Democracy," American Political Science Review, 96(2), 291303.

IARYczower, M., G. Katz, and S. SAiegh (2009): "The not-so-popular branch: Bicameralism as a Counter-Majoritarian Device.," HSS, California Institute of Technology.

IARYCZOWER, M., AND M. Shum (2009): "The Value of Information in the Court. Get it Right, Keep it Tight.," HSS, California Institute of Technology.

IARYczower, M., P. Spiller, And M. Tommasi (2002): "Judicial Independence in Unstable Environments, Argentina 1935-1998," American Journal of Political Science, 46(4), 699-716.

Iaryczower, M., P. Spiller, and M. Tommasi (2006): "Judicial Lobbying: The Politics of Labor Law Constitutional Interpretation," American Political Science Review, 100, 85-97.

KaWAi, K., And Y. Watanabe (2009): "Inferring Strategic Voting," Northwestern University, Department of Economics.

Li, H., S. Rosen, And W. Suen (2001): "Conflicts and Common Interests in Committees," The American Economic Review, 91, 1478-1497. 
LiM, C. (2008): "Turnover and Accountability of Appointed and Elected Judges," Typeset, Stanford University.

Londregan, J. (1999): "Estimating Legislators' Preferred Points," Political Analysis, 8(1), $35-56$.

Martin, A., And K. Quinn (2002): "Dynamic ideal point estimation via Markov chain Monte Carlo for the US Supreme Court, 1953-1999," Political Analysis, 10(2), 134-153.

(2007): "Assessing Preference Change on the US Supreme Court," Journal of Law, Economics and Organization, 23(2), 365-385.

Maskin, E., And J. Tirole (2004): "The politician and the judge: Accountability in government," American Economic Review, 94, 1034-1054.

Poole, K., And H. Rosenthal (1985): "A Spatial Model for Legislative Roll Call Analysis," American Journal of Political Science, 29, 357-384.

35, 228-278.

Spiller, P., AND R. Gely (1992): "Congressional Control or Judicial Independence: The Determinants of U.S. Supreme Court Labor-Relations Decisions, 1949-1988," The RAND Journal of Economics, 23(4), 463-492.

Visser, B., And O. Swank (2007): "On Committees of Experts," Quarterly Journal of Economics, 122, 337-372. 


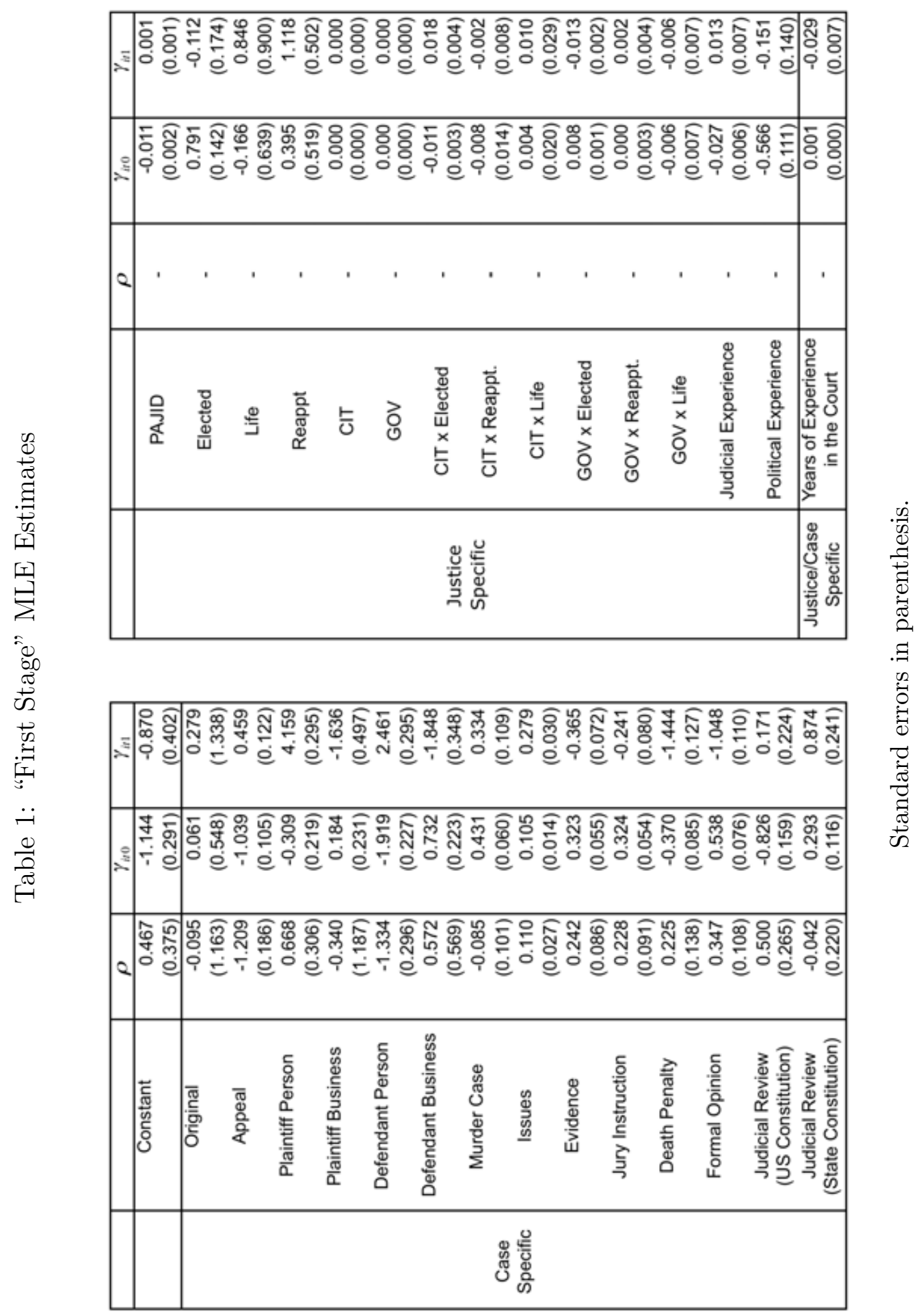




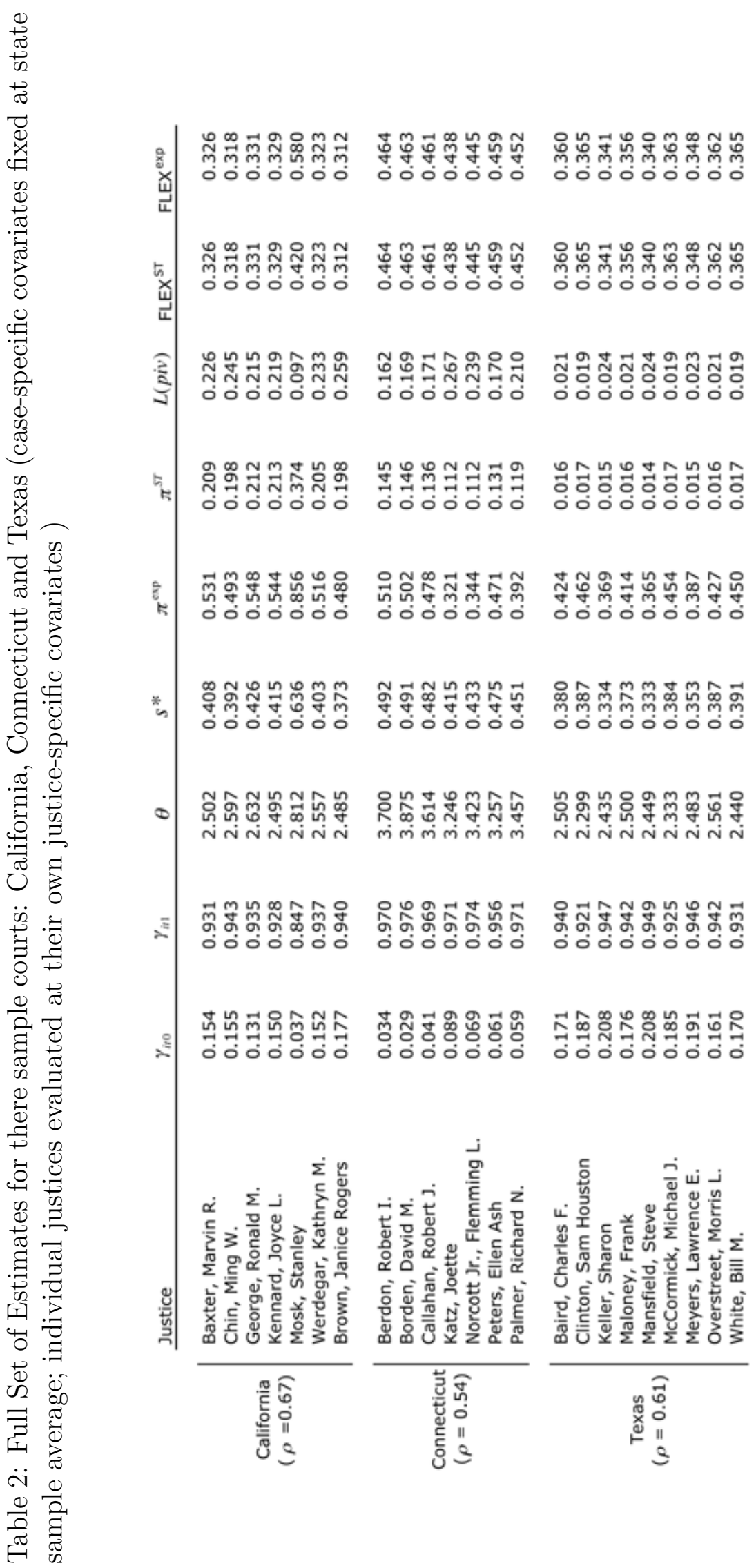




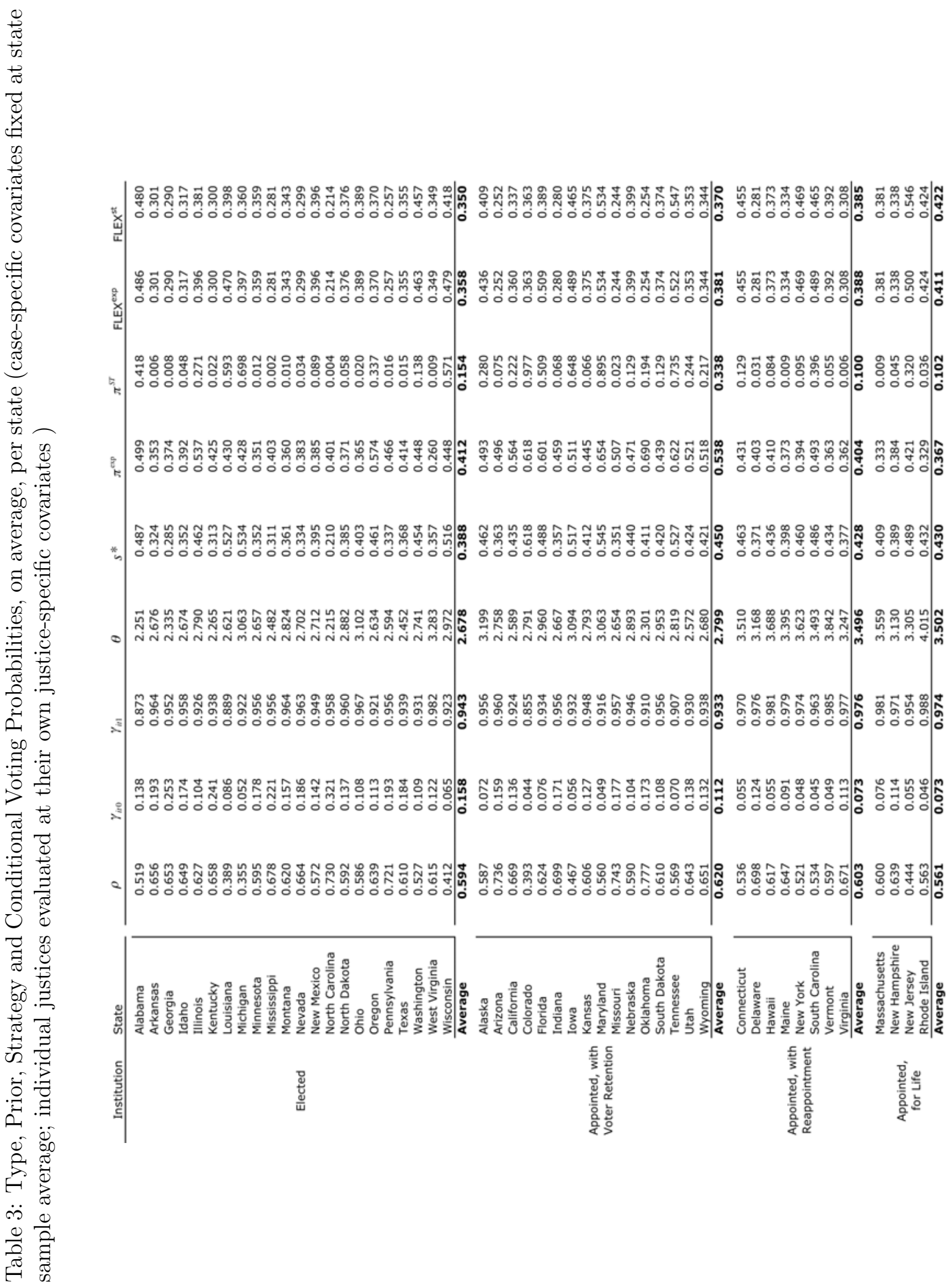




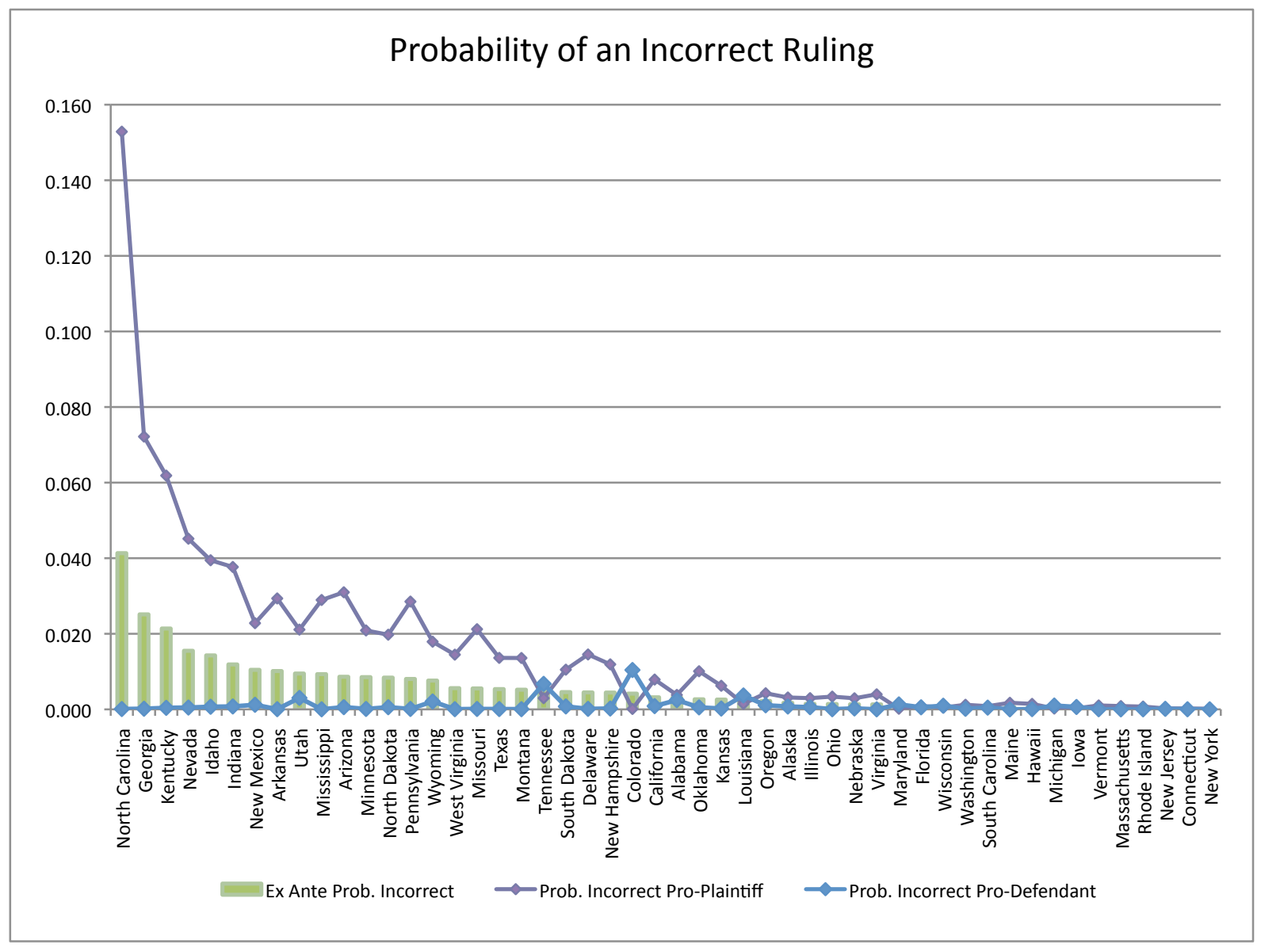

Figure 1: Probability of an incorrect decision at the Court level. Type I and type II errors. 
Table 4: Selection and Incentives

\begin{tabular}{|c|c|c|c|c|c|c|c|}
\hline \multirow[b]{2}{*}{ Institution } & \multirow[b]{2}{*}{ State } & \multicolumn{3}{|c|}{ Quality of Information } & \multicolumn{3}{|c|}{ Bias (Expressive) } \\
\hline & & $\begin{array}{l}\text { Actual } \\
\text { Courts }\end{array}$ & $\begin{array}{l}\text { Fixed } \\
\text { Case }\end{array}$ & $\begin{array}{l}\text { Fixed Case, } \\
\text { Selection \& } \\
\text { Experience }\end{array}$ & $\begin{array}{l}\text { Actual } \\
\text { Courts }\end{array}$ & $\begin{array}{l}\text { Fixed } \\
\text { Case }\end{array}$ & $\begin{array}{l}\text { Fixed Case, } \\
\text { Selection \& } \\
\text { Experience } \\
\end{array}$ \\
\hline \multirow{23}{*}{ Elected } & Alabama & 2.251 & 2.418 & 2.565 & 0.499 & 0.405 & 0.417 \\
\hline & Arkansas & 2.676 & 2.631 & 2.625 & 0.353 & 0.391 & 0.411 \\
\hline & Georgia & 2.335 & 2.365 & 2.185 & 0.374 & 0.438 & 0.460 \\
\hline & Idaho & 2.674 & 2.710 & 2.686 & 0.392 & 0.375 & 0.401 \\
\hline & Illinois & 2.790 & 2.968 & 2.892 & 0.537 & 0.430 & 0.380 \\
\hline & Kentucky & 2.265 & 2.266 & 2.222 & 0.425 & 0.453 & 0.456 \\
\hline & Louisiana & 2.621 & 2.480 & 2.534 & 0.430 & 0.420 & 0.420 \\
\hline & Michigan & 3.063 & 2.950 & 2.933 & 0.428 & 0.405 & 0.373 \\
\hline & Minnesota & 2.657 & 2.720 & 2.716 & 0.351 & 0.388 & 0.400 \\
\hline & Mississippi & 2.482 & 2.478 & 2.491 & 0.403 & 0.428 & 0.424 \\
\hline & Montana & 2.824 & 2.789 & 2.920 & 0.360 & 0.347 & 0.374 \\
\hline & Nevada & 2.702 & 2.416 & 2.485 & 0.383 & 0.458 & 0.427 \\
\hline & New Mexico & 2.712 & 2.639 & 2.568 & 0.385 & 0.396 & 0.418 \\
\hline & North Carolina & 2.215 & 2.397 & 2.433 & 0.401 & 0.425 & 0.433 \\
\hline & North Dakota & 2.882 & 2.846 & 2.953 & 0.371 & 0.362 & 0.371 \\
\hline & Ohio & 3.102 & 2.959 & 2.935 & 0.365 & 0.362 & 0.373 \\
\hline & Oregon & 2.634 & 2.873 & 2.669 & 0.574 & 0.458 & 0.407 \\
\hline & Pennsylvania & 2.594 & 2.887 & 2.922 & 0.466 & 0.360 & 0.376 \\
\hline & Texas & 2.452 & 2.457 & 2.608 & 0.414 & 0.367 & 0.412 \\
\hline & Washington & 2.741 & 2.699 & 2.613 & 0.448 & 0.426 & 0.413 \\
\hline & West Virginia & 3.283 & 2.965 & 2.860 & 0.260 & 0.364 & 0.385 \\
\hline & Wisconsin & 2.972 & 2.815 & 2.804 & 0.448 & 0.405 & 0.390 \\
\hline & Average & 2.678 & 2.669 & 2.664 & 0.412 & 0.403 & 0.406 \\
\hline \multirow{17}{*}{$\begin{array}{l}\text { Appointed, with } \\
\text { Voter Retention }\end{array}$} & Alaska & 3.199 & 2.661 & 2.859 & 0.493 & 0.549 & 0.545 \\
\hline & Arizona & 2.758 & 2.823 & 2.851 & 0.496 & 0.491 & 0.546 \\
\hline & California & 2.589 & 2.757 & 2.856 & 0.564 & 0.514 & 0.545 \\
\hline & Colorado & 2.791 & 2.788 & 2.860 & 0.618 & 0.552 & 0.545 \\
\hline & Florida & 2.960 & 2.904 & 2.860 & 0.601 & 0.556 & 0.545 \\
\hline & Indiana & 2.667 & 2.817 & 2.860 & 0.459 & 0.519 & 0.545 \\
\hline & Iowa & 3.094 & 2.749 & 2.854 & 0.511 & 0.552 & 0.546 \\
\hline & Kansas & 2.793 & 2.790 & 2.852 & 0.445 & 0.521 & 0.546 \\
\hline & Maryland & 3.063 & 3.070 & 2.864 & 0.654 & 0.635 & 0.544 \\
\hline & Missouri & 2.654 & 2.740 & 2.862 & 0.507 & 0.497 & 0.545 \\
\hline & Nebraska & 2.893 & 2.776 & 2.861 & 0.471 & 0.505 & 0.545 \\
\hline & Oklahoma & 2.301 & 2.694 & 2.857 & 0.690 & 0.565 & 0.545 \\
\hline & South Dakota & 2.953 & 2.769 & 2.852 & 0.439 & 0.486 & 0.546 \\
\hline & Tennessee & 2.819 & 2.946 & 2.856 & 0.622 & 0.557 & 0.545 \\
\hline & Utah & 2.572 & 2.636 & 2.852 & 0.521 & 0.515 & 0.546 \\
\hline & Wyoming & 2.680 & 2.705 & 2.853 & 0.518 & 0.506 & 0.546 \\
\hline & Average & 2.799 & 2.789 & 2.857 & 0.538 & 0.533 & 0.545 \\
\hline \multirow{9}{*}{$\begin{array}{l}\text { Appointed, with } \\
\text { Reappointment }\end{array}$} & Connecticut & 3.510 & 3.538 & 3.365 & 0.431 & 0.396 & 0.357 \\
\hline & Delaware & 3.168 & 3.367 & 3.330 & 0.403 & 0.309 & 0.325 \\
\hline & Hawaii & 3.688 & 3.723 & 3.463 & 0.410 & 0.419 & 0.375 \\
\hline & Maine & 3.395 & 3.444 & 3.350 & 0.373 & 0.359 & 0.342 \\
\hline & New York & 3.623 & 3.566 & 3.380 & 0.394 & 0.389 & 0.367 \\
\hline & South Carolina & 3.493 & 3.555 & 3.300 & 0.493 & 0.434 & 0.332 \\
\hline & Vermont & 3.842 & 3.590 & 3.443 & 0.363 & 0.438 & 0.371 \\
\hline & Virginia & 3.247 & 3.199 & 3.287 & 0.362 & 0.324 & 0.323 \\
\hline & Average & 3.496 & 3.498 & 3.365 & 0.404 & 0.383 & 0.349 \\
\hline \multirow{5}{*}{$\begin{array}{l}\text { Appointed, } \\
\text { for Life }\end{array}$} & Massachusetts & 3.559 & 3.512 & 3.509 & 0.333 & 0.387 & 0.359 \\
\hline & New Hampshire & 3.130 & 3.167 & 3.402 & 0.384 & 0.364 & 0.409 \\
\hline & New Jersey & 3.305 & 3.332 & 3.421 & 0.421 & 0.340 & 0.322 \\
\hline & Rhode Island & 4.015 & 3.661 & 3.488 & 0.329 & 0.411 & 0.365 \\
\hline & Average & 3.502 & 3.418 & 3.455 & 0.367 & 0.375 & 0.364 \\
\hline
\end{tabular}




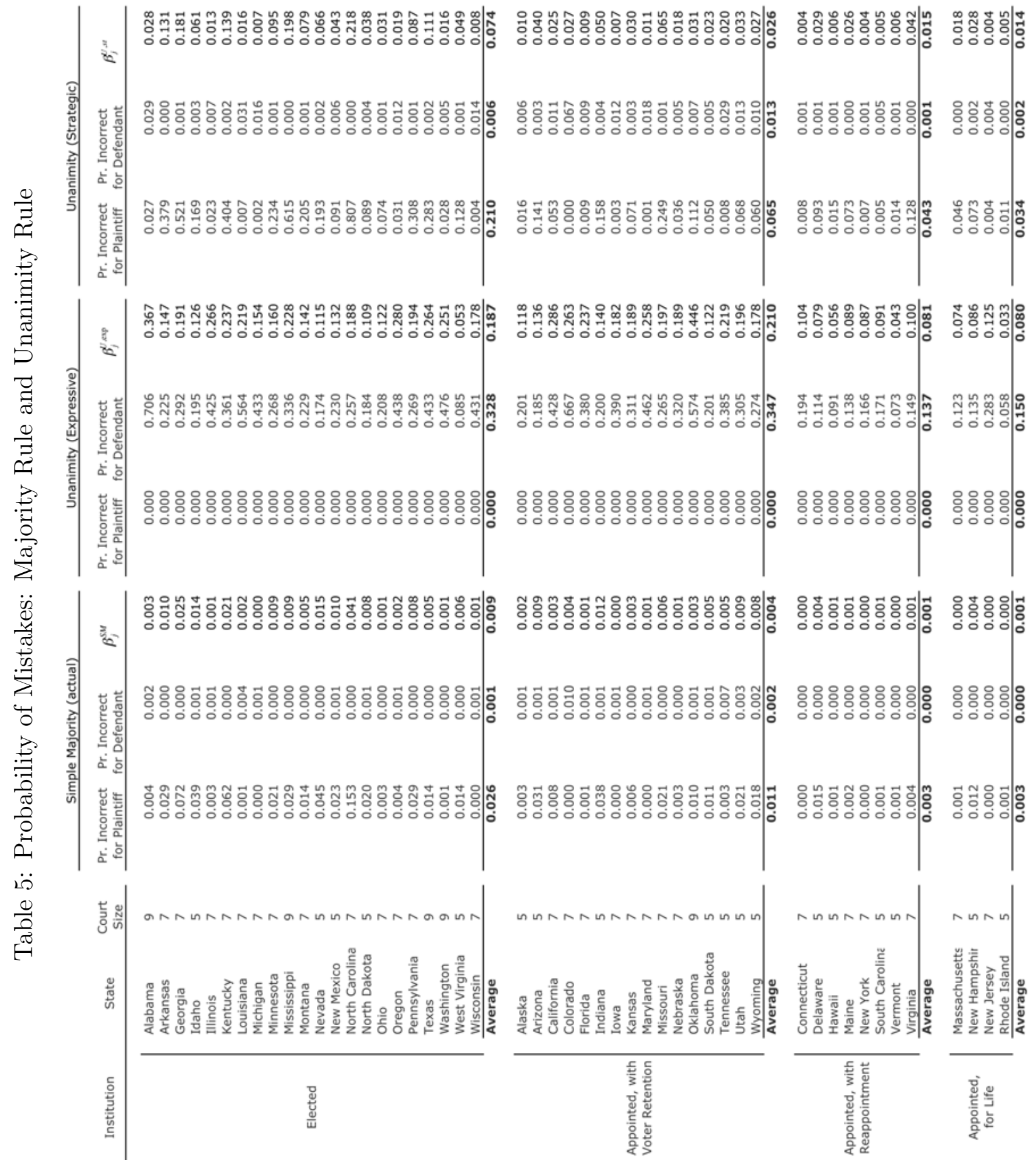


Table 6: "Second-Stage" Estimates and Standard Errors for there sample courts: California, Connecticut and Texas (case-specific covariates fixed at state sample average; individual justices evaluated at their own justice-specific covariates )

\begin{tabular}{|c|c|c|c|c|c|c|c|}
\hline & Justice & $\gamma_{i t 0}$ & $\gamma_{i t 1}$ & $\theta$ & $s *$ & $\pi^{\exp }$ & $\pi^{S T}$ \\
\hline \multirow{13}{*}{$\begin{array}{l}\text { California } \\
(\rho=0.67)\end{array}$} & Baxter, Marvin R. & $\begin{array}{r}0.154 \\
(0.022)\end{array}$ & $\begin{array}{r}0.931 \\
(0.014)\end{array}$ & $\begin{array}{r}2.502 \\
(0.133)\end{array}$ & $\begin{array}{r}0.408 \\
(0.028)\end{array}$ & $\begin{array}{r}0.531 \\
(0.042)\end{array}$ & $\begin{array}{r}0.209 \\
(0.110)\end{array}$ \\
\hline & \multirow[t]{2}{*}{ Chin, Ming W. } & 0.155 & 0.943 & 2.597 & 0.392 & 0.493 & 0.198 \\
\hline & & $(0.022)$ & $(0.012)$ & $(0.127)$ & $(0.028)$ & $(0.049)$ & $(0.106)$ \\
\hline & \multirow[t]{2}{*}{ George, Ronald M. } & 0.131 & 0.935 & 2.632 & 0.426 & 0.548 & 0.212 \\
\hline & & $(0.019)$ & $(0.013)$ & $(0.132)$ & $(0.026)$ & $(0.039)$ & $(0.110)$ \\
\hline & \multirow[t]{2}{*}{ Kennard, Joyce L. } & 0.150 & 0.928 & 2.495 & 0.415 & 0.544 & 0.213 \\
\hline & & $(0.022)$ & $(0.014)$ & $(0.137)$ & $(0.028)$ & $(0.040)$ & $(0.111)$ \\
\hline & \multirow[t]{2}{*}{ Mosk, Stanley } & 0.037 & 0.847 & 2.812 & 0.636 & 0.856 & 0.374 \\
\hline & & $(0.012)$ & $(0.035)$ & $(0.238)$ & $(0.033)$ & $(0.059)$ & $(0.130)$ \\
\hline & \multirow[t]{2}{*}{ Werdegar, Kathryn M. } & 0.152 & 0.937 & 2.557 & 0.403 & 0.516 & 0.205 \\
\hline & & $(0.021)$ & $(0.013)$ & $(0.127)$ & $(0.027)$ & $(0.044)$ & $(0.108)$ \\
\hline & \multirow[t]{2}{*}{ Brown, Janice Rogers } & 0.177 & 0.940 & 2.485 & 0.373 & 0.480 & 0.198 \\
\hline & & $(0.024)$ & $(0.012)$ & $(0.127)$ & $(0.030)$ & $(0.051)$ & $(0.107)$ \\
\hline \multirow{14}{*}{$\begin{array}{c}\text { Connecticut } \\
(\rho=0.54)\end{array}$} & \multirow[t]{2}{*}{ Berdon, Robert I. } & 0.034 & 0.970 & 3.700 & 0.492 & 0.510 & 0.145 \\
\hline & & $(0.024)$ & $(0.017)$ & $(0.523)$ & $(0.031)$ & $(0.049)$ & $(0.219)$ \\
\hline & \multirow[t]{2}{*}{ Borden, David M. } & 0.029 & 0.976 & 3.875 & 0.491 & 0.502 & 0.146 \\
\hline & & $(0.021)$ & $(0.014)$ & $(0.522)$ & $(0.028)$ & $(0.051)$ & $(0.220)$ \\
\hline & \multirow[t]{2}{*}{ Callahan, Robert J. } & 0.041 & 0.969 & 3.614 & 0.482 & 0.478 & 0.136 \\
\hline & & $(0.029)$ & $(0.018)$ & $(0.542)$ & $(0.031)$ & $(0.061)$ & $(0.216)$ \\
\hline & \multirow[t]{2}{*}{ Katz, Joette } & 0.089 & 0.971 & 3.246 & 0.415 & 0.321 & 0.112 \\
\hline & & $(0.059)$ & $(0.017)$ & $(0.579)$ & $(0.048)$ & $(0.197)$ & $(0.205)$ \\
\hline & \multirow[t]{2}{*}{ Norcott Jr., Flemming L. } & 0.069 & 0.974 & 3.423 & 0.433 & 0.344 & 0.112 \\
\hline & & $(0.047)$ & $(0.015)$ & $(0.563)$ & $(0.042)$ & $(0.174)$ & $(0.202)$ \\
\hline & \multirow[t]{2}{*}{ Peters, Ellen Ash } & 0.061 & 0.956 & 3.257 & 0.475 & 0.471 & 0.131 \\
\hline & & $(0.042)$ & $(0.025)$ & $(0.576)$ & $(0.037)$ & $(0.069)$ & $(0.217)$ \\
\hline & \multirow[t]{2}{*}{ Palmer, Richard N. } & 0.059 & 0.971 & 3.457 & 0.451 & 0.392 & 0.119 \\
\hline & & $(0.041)$ & $(0.017)$ & $(0.559)$ & $(0.037)$ & $(0.133)$ & $(0.207)$ \\
\hline \multirow{18}{*}{$\begin{array}{c}\text { Texas } \\
(\rho=0.61)\end{array}$} & \multirow[t]{2}{*}{ Baird, Charles F. } & 0.171 & 0.940 & 2.505 & 0.380 & 0.424 & 0.016 \\
\hline & & $(0.025)$ & $(0.011)$ & $(0.153)$ & $(0.024)$ & $(0.053)$ & $(0.019)$ \\
\hline & \multirow[t]{2}{*}{ Clinton, Sam Houston } & 0.187 & 0.921 & 2.299 & 0.387 & 0.462 & 0.017 \\
\hline & & $(0.032)$ & $(0.014)$ & $(0.179)$ & $(0.030)$ & $(0.047)$ & $(0.020)$ \\
\hline & \multirow[t]{2}{*}{ Keller, Sharon } & 0.208 & 0.947 & 2.435 & 0.334 & 0.369 & 0.015 \\
\hline & & $(0.028)$ & $(0.009)$ & $(0.146)$ & $(0.026)$ & $(0.062)$ & $(0.019)$ \\
\hline & \multirow[t]{2}{*}{ Maloney, Frank } & 0.176 & 0.942 & 2.500 & 0.373 & 0.414 & 0.016 \\
\hline & & $(0.025)$ & $(0.010)$ & $(0.151)$ & $(0.024)$ & $(0.055)$ & $(0.019)$ \\
\hline & \multirow{2}{*}{ Mansfield, Steve } & 0.208 & 0.949 & 2.449 & 0.333 & 0.365 & 0.014 \\
\hline & & $(0.028)$ & $(0.009)$ & $(0.145)$ & $(0.026)$ & $(0.063)$ & $(0.018)$ \\
\hline & McCormick, Michael J. & 0.185 & 0.925 & 2.333 & 0.384 & 0.454 & 0.017 \\
\hline & & $(0.031)$ & $(0.013)$ & $(0.174)$ & $(0.028)$ & $(0.049)$ & $(0.020)$ \\
\hline & Meyers, Lawrence E. & 0.191 & 0.946 & 2.483 & 0.353 & 0.387 & 0.015 \\
\hline & & $(0.027)$ & $(0.010)$ & $(0.148)$ & $(0.025)$ & $(0.060)$ & $(0.018)$ \\
\hline & Overstreet, Morris L. & 0.161 & 0.942 & 2.561 & 0.387 & 0.427 & 0.016 \\
\hline & & $(0.024)$ & $(0.010)$ & $(0.151)$ & $(0.023)$ & $(0.051)$ & $(0.020)$ \\
\hline & White, Bill M. & 0.170 & 0.931 & 2.440 & 0.391 & 0.450 & 0.017 \\
\hline & & $(0.027)$ & $(0.012)$ & $(0.164)$ & $(0.025)$ & $(0.049)$ & $(0.021)$ \\
\hline
\end{tabular}




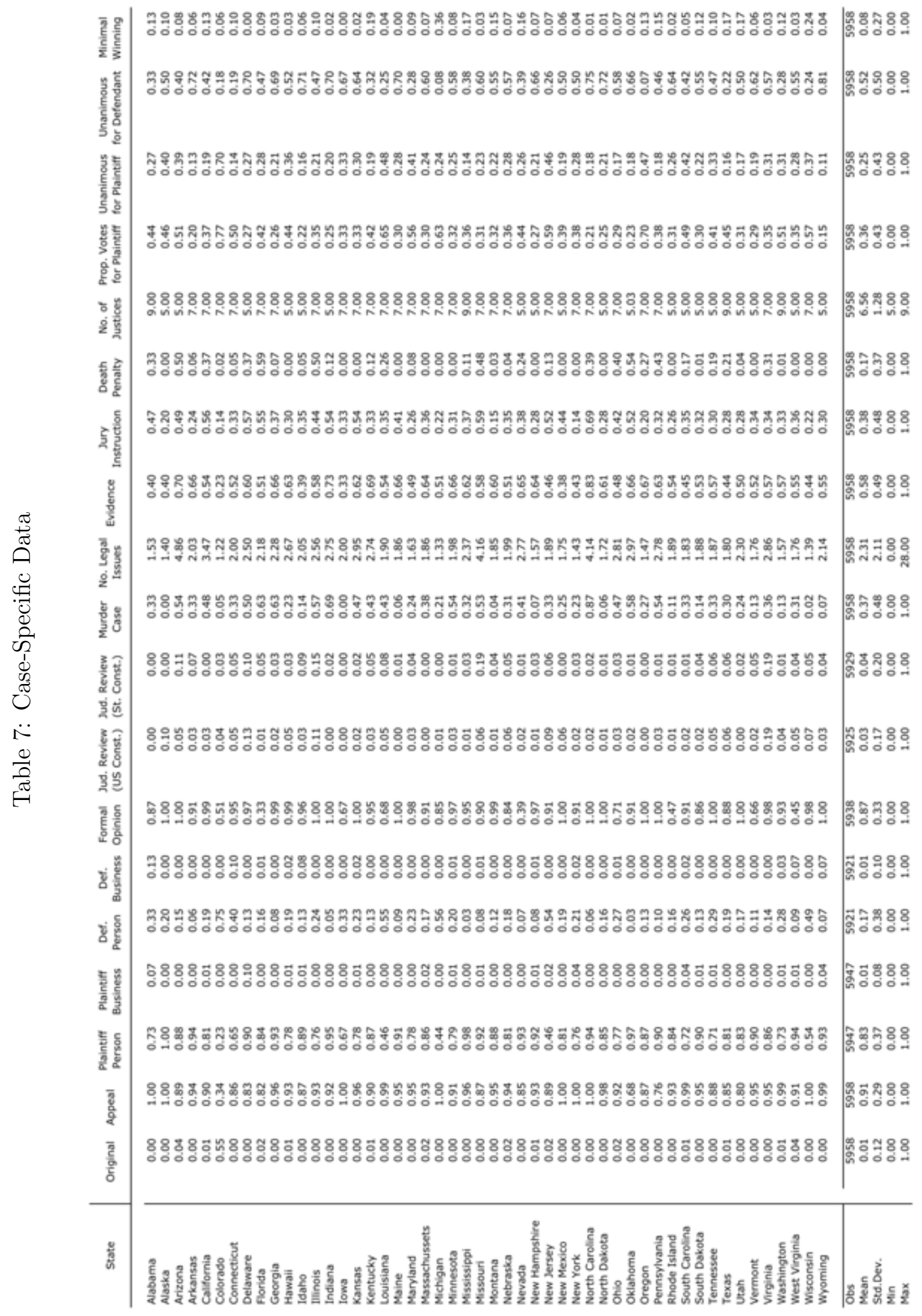


Table 8: Justice-Specific Data

Justices in Largest Natural Courts (LNC) in Each State. Average Values of Justice-Specific Covariates, per State (324 Justices)

\begin{tabular}{|c|c|c|c|c|c|c|c|c|c|}
\hline State & Elected & Apptd for life & $\begin{array}{l}\text { Appt. w/ Pol. } \\
\text { Reappointment }\end{array}$ & $\begin{array}{c}\text { Prior Judicial } \\
\text { Experience }\end{array}$ & $\begin{array}{c}\text { Prior Political } \\
\text { Experience }\end{array}$ & $\begin{array}{c}\text { Years of } \\
\text { Experience }\end{array}$ & $\begin{array}{c}\text { PAJID at } \\
\text { appointment }\end{array}$ & $\begin{array}{c}\text { CIT at } \\
\text { decision }\end{array}$ & $\begin{array}{l}\text { GOV at } \\
\text { decision }\end{array}$ \\
\hline Alabama & 1.00 & 0.00 & 0.00 & 5.13 & 0.00 & 12.15 & 33.59 & 41.37 & 45.13 \\
\hline Alaska & 0.00 & 0.00 & 0.00 & 2.40 & 0.00 & 15.34 & 41.77 & 22.34 & 33.87 \\
\hline Arizona & 0.00 & 0.00 & 0.00 & 9.20 & 0.00 & 5.71 & 25.32 & 40.26 & 1.64 \\
\hline Arkansas & 1.00 & 0.00 & 0.00 & 5.00 & 0.14 & 5.36 & 39.23 & 47.00 & 46.83 \\
\hline California & 0.00 & 0.00 & 0.00 & 5.43 & 0.14 & 8.80 & 29.22 & 55.65 & 44.08 \\
\hline Colorado & 0.00 & 0.00 & 0.00 & 3.83 & 0.14 & 10.63 & 42.56 & 42.48 & 55.92 \\
\hline Connecticut & 0.00 & 0.00 & 1.00 & 10.29 & 0.14 & 7.29 & 57.87 & 58.98 & 42.62 \\
\hline Delaware & 0.00 & 0.00 & 1.00 & 8.40 & 0.00 & 6.41 & 42.79 & 43.79 & 53.75 \\
\hline Florida & 0.00 & 0.00 & 0.00 & 8.71 & 0.00 & 9.68 & 49.50 & 44.60 & 55.27 \\
\hline Georgia & 1.00 & 0.00 & 0.00 & 11.83 & 0.00 & 2.92 & 45.49 & 41.77 & 85.34 \\
\hline Hawaii & 0.00 & 0.00 & 1.00 & 7.20 & 0.00 & 4.44 & 82.22 & 79.81 & 93.88 \\
\hline Idaho & 1.00 & 0.00 & 0.00 & 7.60 & 0.20 & 4.73 & 30.74 & 20.35 & 2.38 \\
\hline Illinois & 1.00 & 0.00 & 0.00 & 13.83 & 0.14 & 13.84 & 44.93 & 59.93 & 36.68 \\
\hline Indiana & 0.00 & 0.00 & 0.00 & 1.00 & 0.00 & 6.22 & 50.25 & 40.30 & 51.84 \\
\hline Iowa & 0.00 & 0.00 & 0.00 & 9.86 & 0.14 & 13.93 & 25.27 & 40.77 & 20.92 \\
\hline Kansas & 0.00 & 0.00 & 0.00 & 9.83 & 0.14 & 9.18 & 21.20 & 36.08 & 6.08 \\
\hline Kentucky & 1.00 & 0.00 & 0.00 & 9.29 & 0.14 & 7.71 & 37.83 & 36.46 & 73.96 \\
\hline Louisiana & 1.00 & 0.00 & 0.00 & 9.00 & 0.14 & 10.82 & 29.80 & 35.13 & 39.58 \\
\hline Maine & 0.00 & 0.00 & 1.00 & 6.29 & 0.00 & 7.34 & 61.16 & 52.20 & 48.38 \\
\hline Maryland & 0.00 & 0.00 & 0.00 & 9.00 & 0.14 & 11.42 & 78.04 & 58.37 & 90.17 \\
\hline Massachusetts & 0.00 & 1.00 & 0.00 & 5.86 & 0.00 & 11.24 & 55.51 & 86.47 & 79.78 \\
\hline Michigan & 1.00 & 0.00 & 0.00 & 7.43 & 0.14 & 11.54 & 47.79 & 48.45 & 15.77 \\
\hline Minnesota & 1.00 & 0.00 & 0.00 & 2.50 & 0.14 & 5.06 & 46.35 & 49.55 & 40.83 \\
\hline Mississippi & 1.00 & 0.00 & 0.00 & 6.33 & 0.33 & 7.74 & 30.75 & 23.78 & 27.88 \\
\hline Missouri & 0.00 & 0.00 & 0.00 & 3.29 & 0.14 & 6.54 & 24.97 & 46.33 & 70.91 \\
\hline Montana & 1.00 & 0.00 & 0.00 & 0.86 & 0.14 & 6.83 & 32.68 & 41.62 & 7.50 \\
\hline Nebraska & 0.00 & 0.00 & 0.00 & 2.71 & 0.00 & 6.76 & 38.82 & 32.68 & 53.00 \\
\hline Nevada & 1.00 & 0.00 & 0.00 & 3.00 & 0.60 & 9.56 & 27.14 & 39.51 & 50.91 \\
\hline New Hampshire & 0.00 & 1.00 & 0.00 & 5.00 & 0.25 & 10.09 & 4.23 & 38.55 & 43.80 \\
\hline New Jersey & 0.00 & 0.71 & 0.29 & 5.00 & 0.14 & 12.67 & 39.06 & 61.72 & 23.43 \\
\hline New Mexico & 1.00 & 0.00 & 0.00 & 8.00 & 0.00 & 5.18 & 45.09 & 44.83 & 49.75 \\
\hline New York & 0.00 & 0.00 & 1.00 & 13.14 & 0.00 & 7.45 & 56.16 & 64.28 & 43.68 \\
\hline North Carolina & 1.00 & 0.00 & 0.00 & 6.29 & 0.14 & 8.38 & 35.00 & 42.29 & 60.33 \\
\hline North Dakota & 1.00 & 0.00 & 0.00 & 2.60 & 0.20 & 8.29 & 32.83 & 51.87 & 18.53 \\
\hline Ohio & 1.00 & 0.00 & 0.00 & 7.71 & 0.14 & 6.58 & 36.99 & 48.07 & 15.00 \\
\hline Oklahoma & 0.00 & 0.00 & 0.00 & 6.44 & 0.00 & 17.08 & 39.01 & 9.25 & 10.54 \\
\hline Oregon & 1.00 & 0.00 & 0.00 & 8.71 & 0.29 & 6.91 & 60.50 & 56.54 & 55.79 \\
\hline Pennsylvania & 1.00 & 0.00 & 0.00 & 4.86 & 0.00 & 7.86 & 43.74 & 56.29 & 28.23 \\
\hline Rhode Island & 0.00 & 1.00 & 0.00 & 12.25 & 0.40 & 6.01 & 41.10 & 77.11 & 71.08 \\
\hline South Carolina & 0.00 & 0.00 & 1.00 & 11.40 & 1.00 & 5.92 & 35.00 & 41.37 & 24.45 \\
\hline South Dakota & 0.00 & 0.00 & 0.00 & 7.20 & 0.00 & 6.39 & 23.66 & 42.13 & 9.00 \\
\hline Tennessee & 0.00 & 0.00 & 0.00 & 6.80 & 0.20 & 6.13 & 48.20 & 32.02 & 24.18 \\
\hline Texas & 1.00 & 0.00 & 0.00 & 0.89 & 0.00 & 6.96 & 34.14 & 34.80 & 31.33 \\
\hline Utah & 0.00 & 0.00 & 0.00 & 3.20 & 0.00 & 12.50 & 28.66 & 36.77 & 5.30 \\
\hline Vermont & 0.00 & 0.00 & 1.00 & 6.80 & 0.20 & 9.46 & 66.85 & 75.46 & 83.99 \\
\hline Virginia & 0.00 & 0.00 & 1.00 & 8.43 & 0.00 & 12.81 & 34.56 & 36.51 & 25.51 \\
\hline Washington & 1.00 & 0.00 & 0.00 & 6.88 & 0.11 & 7.19 & 52.57 & 50.96 & 53.79 \\
\hline West Virginia & 1.00 & 0.00 & 0.00 & 8.20 & 0.20 & 2.60 & 38.23 & 70.14 & 54.62 \\
\hline Wisconsin & 1.00 & 0.00 & 0.00 & 9.71 & 0.29 & 9.57 & 30.55 & 52.42 & 35.50 \\
\hline Wyoming & 0.00 & 0.00 & 0.00 & 4.40 & 0.00 & 9.58 & 29.45 & 31.20 & 4.17 \\
\hline Average in LNCs & 0.47 & 0.07 & 0.15 & 6.77 & 0.13 & 8.66 & 40.72 & 46.02 & 41.08 \\
\hline \multicolumn{10}{|l|}{ Full Sample } \\
\hline Obs. & 520 & 520 & 520 & 507 & 507 & 510 & 453 & 520 & 520 \\
\hline Mean & 0.49 & 0.06 & 0.16 & 6.87 & 0.15 & 5.50 & 39.49 & 45.85 & 41.02 \\
\hline Std.Dev. & 0.50 & 0.24 & 0.36 & 7.06 & 0.36 & 7.34 & 22.59 & 14.97 & 22.88 \\
\hline Min. & 0.00 & 0.00 & 0.00 & 0.00 & 0.00 & 0.00 & 1.25 & 9.25 & 1.64 \\
\hline Max. & 1.00 & 1.00 & 1.00 & 35.00 & 1.00 & 62.70 & 96.62 & 86.47 & 93.88 \\
\hline
\end{tabular}

